\title{
Inosine Pranobex: A Key Player in the Game Against a Wide Range of Viral Infections and Non-Infectious Diseases
}

\author{
Jiri Sliva $\cdot$ Chrysoula N. Pantzartzi (1) $\cdot$ Martin Votava
}

Received: April 6, 2019 / Published online: June 5, 2019

(c) The Author(s) 2019

\begin{abstract}
Inosine pranobex (IP), commonly known as inosine acedoben dimepranol, isoprinosine and methisoprinol, has been proven to positively impact the host's immune system, by enhancing T-cell lymphocyte proliferation and activity of natural killer cells, increasing levels of proinflammatory cytokines, and thereby restoring deficient responses in immunosuppressed patients. At the same time, it has been shown that it can affect viral RNA levels and hence inhibit growth of several viruses. Due to its immunomodulatory and antiviral properties, and its safety profile, it has been widely used since 1971 against viral infections and diseases, among which subacute sclerosis panencephalitis, herpes simplex virus, human papilloma virus, human immunodeficiency virus, influenza and acute respiratory infections, cytomegalovirus and Epstein-Barr virus infections.
\end{abstract}

Enhanced digital features To view enhanced digital features for this article go to https://doi.org/10.6084/ m9.figshare.8124878.

\section{J. Sliva}

Department of Pharmacology, 3rd Faculty of Medicine, Charles University, Prague, Czech Republic

C. N. Pantzartzi $(\bowtie) \cdot$ M. Votava

Institute of Pharmacovigilance, Prague, Czech

Republic

e-mail: chrysoula.pantzartzi@primevigilance.com
Following an analysis of almost five decades of scientific literature since its original approval, we here summarize in vivo and in vitro studies manifesting the means in which IP impacts the host's immune system. We also provide a synopsis of therapeutic trials in the majority of which IP was found to have a beneficial effect. Lastly, positive results from limited studies, suggesting the putative future use of IP in new therapeutic indications are briefly described. In order to support use of IP against viral infections apart from those already approved, and to establish its use in clinical practice, further welldesigned and executed trials are warranted.

Funding: Ewopharma International.

Keywords: Antiviral; Herpes; HPV; Immunomodulation; Infection; Influenza; Inosine pranobex; Isoprinosine; SSPE

\section{INTRODUCTION}

Inosine pranobex (IP), commonly known as inosine acedoben dimepranol, isoprinosine or methisoprinol, is a synthetic compound of the p-acetamido-benzoate salt of $N-N$ dimethylamino-2-propanol with inosine in a 3:1 molar ratio, with immunomodulatory and antiviral properties. The drug was initially authorised in 1971 and is currently marketed in more than 70 countries worldwide for the treatment of viral 
diseases, including subacute sclerosing panencephalitis (SSPE), herpes simplex virus (HSV) and varicella infections, human papilloma virus (HPV), cytomegalovirus and Epstein-Barr virus infections, acute viral respiratory infections, measles, and immunosuppressed states.

Results from numerous studies as early as the 1970s and 1980s suggested beneficial effects of treatment with IP in several diseases and infections, among which were HSV infections, SSPE, genital warts, influenza, etc. To date, it is uniformly supported that IP is a drug which is well tolerated and free from serious side effects. This fact is supported both by the small number of adverse reactions and the limited number of subjects withdrawn from clinical trials, as well as available post-marketing exposure data from patients treated with IP. In long-term treatments and large doses, transient nausea may occur [1]. A transient rise of serum and urinary uric acid concentrations, owing to inosine metabolism, is the most commonly reported side effect and is more pronounced in males. Nevertheless, hyperuricemia was found to be generally reversible [1-4]. Based on results from cytotoxic assays, comet and micronucleus assay, and Ames testing, it was concluded that IP is neither cytotoxic, genotoxic nor mutagenic [5-8].

IP's antiviral and antitumor activities have been demonstrated both in vitro and in vivo and are considered secondary to an immunomodulating effect; nevertheless, the exact mechanism of action is not yet clearly defined. The occurrence of drug-resistant viral strains against traditional antiviral agents underlines the need to further exploit the respective properties of IP, in order to expand the existing arsenal against viral diseases. IP continues to be the subject of various clinical and non-clinical studies. Its efficacy, either as monotherapy or as part of a combination therapy, has been re-visited for various diseases. Moreover, new, potentially therapeutic indications for IP or new agents for concomitant administration have been investigated.

We here present a synopsis of in vitro and in vivo studies which support the immunomodulatory and antiviral properties of IP, and, consequently, unveil its pleiotropic mode of action and justify its beneficial effect on various diseases and infections, as exemplified in multiple therapeutic trials.

This article is based on previously conducted studies and does not contain any studies with human participants or animals performed by any of the authors.

\section{MECHANISM OF ACTION}

For decades now, IP has been a widely used drug due to its immunomodulatory and antiviral properties, and several mechanisms of action have been postulated in an effort to explain these properties. Studies have shown that IP can impact both the humoral as well as the cell-mediated aspects of the immune system, in such a way that it enhances the host immune responses and can also exhibit antiviral effects considered secondary to this immunopotentiation.

Administration of IP apparently induces a Th1 cell-type response, evidenced by an increase in the levels of pro-inflammatory cytokines (e.g., IL-2, IFN- $\gamma$ ), both in vivo and in vitro, in mitogen- or antigen-activated cells [9-12]. This response initiates T-lymphocyte maturation and differentiation and potentiates induced lymphoproliferative responses [10-13]. It has been reported that IFN- $\gamma$ inhibits production of IL-10 [14], which, in combination with the drug-induced decrease in the production of IL-10 and other anti-inflammatory cytokines, suggests that IP could modulate the suppressive effect of these cytokines on innate and adaptive immunity. IP's potential against viral infections is also supported by the increase in natural killer (NK) cells population and increased NK activity [12, 13, 15-19]. Neutrophil, monocyte and macrophage chemotaxis and phagocytosis are also potentiated by IP $[12,13,20]$, while NK activity of eosinophils is enhanced due to an increase of the number of $\lg \mathrm{G}$ and complement surface markers triggered by IP administration [21].

The humoral immune response is mainly increased by stimulation of B lymphocyte differentiation into plasma cells and the enhancement of antibody production [22, 23].

In an attempt to explain the antiviral properties of IP, various hypotheses have been 
formed. The in vivo antiviral activity of IP is believed to result from an enhancement of host immune responses due to the drug [20]. In that view, the drug augments immunological processes by lymphocytes once they have been triggered by viral antigens, as it is not able to stimulate resting lymphocytes by itself $[10,20,22,24]$. Notwithstanding, there may be other possible modes of action.

IP has been found to stimulate a nonspecific immune response, independent of the specific viral antigen [6], which presumably indicates that its viral inhibitory effects can also be placed on the level of transcription and translation. In fact, on one hand, cellular RNA and protein synthesis are markedly depressed shortly after viral infection, and on the other hand, IP enhances host cell RNA and synthesis and decreases viral RNA synthesis [22, 25].

It has been suggested that one of the drug components or even the drug complex itself links to the ribosomes of the infected cells, provoking a steric modification of host ribosomal structure, thus providing an advantage to host cellular RNA over viral RNA in the competition for linkage with the ribosomal combining sites [25]. The consequence would be a non-reading or incorrect reading of the viral genome, with incorrect transcription of the viral genetic code [26].

Another hypothesis is based on the rapid metabolism of IP and the inhibitory role of inosine. It was assumed that, prior to its metabolization, IP is dissociated into its constituents, i.e., three molecules of $N-N$ dimethylamino-2propanol- $p$-acetamidobenzoate and one molecule of inosine, of which the latter inhibits the synthesis of the phosphoribosyl pyrophosphate, an intermediate in the biosynthesis of purine nucleotides such as adenylate and guanylate. Since IP inhibits the conversion of ribose phosphate to phosphoribosyl pyrophosphate, it may act by blocking the synthesis of viral RNA, as this process is faster than cellular RNA synthesis [27].

In light of a new study unveiling inosine's ability to cause ribosome stalling and contextdependent decoding during translation (to either adenosine or uracil) [28], more focus should be placed on the impact of IP at the transcriptional and translational level, in order to fully elucidate its mode of action in viral replication.

Based on the described IP effects and hypotheses, we can conclude that its action remains elusive, but undoubtedly pleiotropic. Overall, the drug may act to restore depressed T-lymphocyte function to normal by increasing lymphokine production, or alternatively by increasing cell ribosomal RNA and protein synthesis while simultaneously inhibiting the use of cell ribosomal RNA for viral replication. The in vivo and in vitro studies exhibiting immunomodulatory and antiviral properties of IP are outlined in the following sections.

\section{IMMUNOMODULATING ACTIVITY}

Early in vivo and in vitro studies on the immunomodulating activity of IP, dating roughly back to the first two decades of its use, have been presented in various review papers [1, 8, 29-32]. We here summarize the main findings from these studies together with results from more recent publications which may shed further light on the pharmacological activity of IP (Table 1).

The impact of IP on Th1- and Th2-related cytokines has been investigated in vitro both in human and animal cells. Levels of studied cytokines remained unchanged in resting lymphocytes, incubated with IP. In contrast, IP has been reported to increase the production of IL-2, interferongamma (IFN- $\gamma$ ) and tumor necrosis alpha (TNF- $\alpha$ ), and to decrease the production of IL-4, IL- 5 and IL10, in mitogen-stimulated cells [10-12].

In vitro, IP appeared to improve or restore the impaired chemotaxis and phagocytosis of neutrophils [12]. In patients with parasitic infections, exposure to IP increased the receptors for the FC fragment of IgG and for C3 of eosinophils and enhanced their killer functions against nucleated target cells [21].

B lymphocyte differentiation may be promoted by IP, but the effect of the drug on B cells may result from its effect on macrophage or T-helper cells [33]. Additionally, the drug induced an early chromatin activation in peripheral blood mononuclear cells from patients with the acquired immunodeficiency syndrome (AIDS)-related complex (ARC) [34]. 


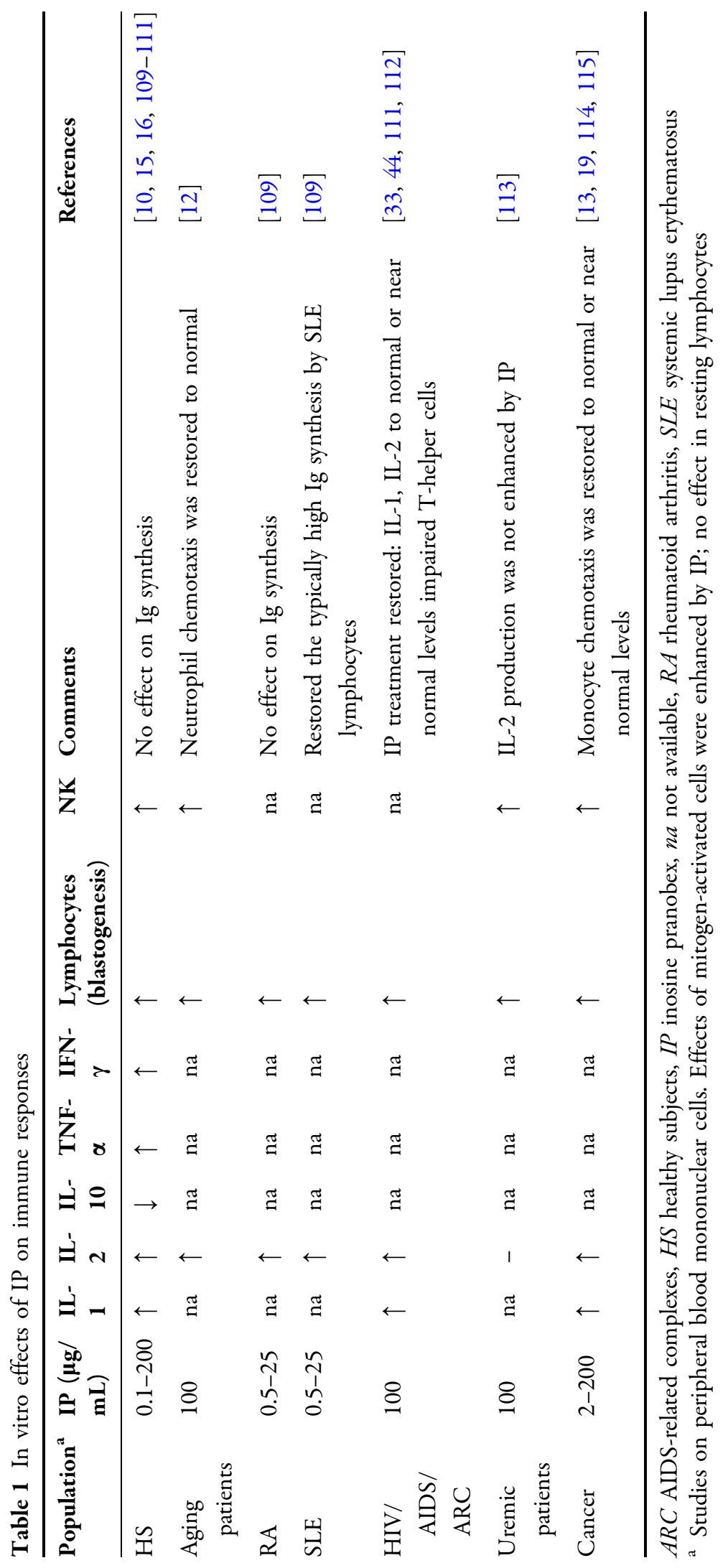


Several mediators of immune function were stimulated by IP and the upregulation of the host protective Th1 cells in parallel with the downregulation of Th2 cells was evidenced in vivo in various experimental animal models $[11,35]$. In vitro production of IFN- $\gamma$ was significantly increased in murine lymphocytes, as opposed to IL-3 and IL-4, and there was no effect on NK cells or on antibody-dependent cellular cytotoxicity $[20,35]$. In an experimental mouse model of the Epstein-Barr virus, a 14-day treatment with IP resulted in an increased number of leukocytes, an increased percentage of neutrophils, and a reduced number of atypical lymphocytes [36].

Pharmacodynamic, in vivo studies in healthy subjects are rather limited. The serum levels of certain cytokines during and after IP treatment were determined in 10 healthy volunteers with a mean age of 41 years, to whom $1 \mathrm{~g}$ of IP was administered thrice daily, for 3 weeks (5 consecutive days weekly). An increase in the proinflammatory cytokines was observed, while fluctuations of cytokine levels were found to correlate with the treatment scheme applied [9]. Daily administration of $4 \mathrm{~g}$ of IP in 21 healthy individuals resulted in a rapid response in a high percentage of participants, an increase in the number of lymphocytes and a circadian fluctuation of them in the peripheral blood [37]. An early rise in NK cells (as a percentage of total peripheral blood lymphocytes), maintained at the termination of the study was observed in 10 healthy volunteers, to whom $4 \mathrm{~g}$ of IP were administered daily for 14 days [15].

Various studies have focused on the effect of IP on the immune system of patients affected by different diseases. In patients with herpes virus infection, higher lymphocyte transformation was observed in treated individuals than in the control group [38]. In patients with autoimmune diseases, like aphthous stomatitis or alopecia, IP was found to increase the number of active T-cell rosettes and enhanced responses to mitogen activation [39-41]. A similar increase, a renewal in depleted T-cells and seroconversion to anti-HBe was achieved in patients with chronic active hepatitis B $[42,43]$. Patients with persistent generalised lymphadenopathy (PGL) or ARC exhibited significant increase in the number of NK cells and NK activity, which lasted up to 5 months after cessation of IP [18]. Treatment with IP also resulted in enhanced NK cell activity as well as increased numbers of CD4+T-helper cells in clinically improved patients with chronic fatigue syndrome (CFS) [17].

In summary, IP potentiates or enhances immunological events (e.g., production of cytokines, differentiation of cells of the T-lymphocyte lineage) initiated by other triggering agents such as mitogens, antigens, phagocytic stimuli or lymphokines. The impact of IP on NK cells and NK activity has also been demonstrated.

\section{ANTIVIRAL ACTIVITY}

The production of effective antiviral drugs is in general a difficult and time-consuming process, and the emergence of resistant strains owing to extended use of antiviral drugs, is a key issue in the development of novel antivirals, as for example in the case of herpes infections. A useful strategy would be to optimize the efficacy and selectivity of existing antiviral drugs by combining them with other well-known agents that could potentiate their effect.

The antiviral effect of IP has been extensively reviewed by Campoli-Richards et al. [31], and found to be modest and inconsistent in standard tissue cultures. IP was successful in inhibiting the replication of several RNA and DNA viruses, among which are HSV, cytomegalovirus, LAV/HTLV-III virus, adenovirus 10, vaccinia virus, polio virus, influenza types $A$ and $B$ viruses, rhinovirus, rabies virus, viral encephalomyocarditis, enteric cytopathic human orphan virus and eastern equine encephalitis virus. In contrast, a lack of efficacy has been noted for parainfluenza virus, measles virus, mumps virus, rhinovirus and western equine encephalitis virus [31].

To date, there has been an ongoing in vitro investigation of the antiviral properties of IP on new target viruses, as well as on different strains of already studied viruses. IP has been found to possesses a weak anti-HIV-1 activity in human peripheral blood mononuclear cells [44]. 
Inhibition of viral RNA synthesis was achieved at a concentration of $1 \mathrm{mg} / \mathrm{mL}$ IP at $72 \mathrm{~h}$ after infection of MA-104 cells with the simian rotavirus strain SA-11 [27]. In a recent study, IP was found to strongly inhibit the multiplication of adenoviruses (HAdV-2 and HAdV-5), in particular in combination with IFN- $\alpha$ [45].

No vaccine is currently available to prevent herpes infections. Acyclovir is the first selective inhibitor of alphaherpesviruses and consequently is the treatment of choice for HSV-1 and HSV-2 infections. However, the high prevalence of HSV strains with reduced susceptibility to acyclovir in immunocompromised patients [46] and the low oral bioavailability and adverse effects of the second line treatments (e.g., foscarnet, cidofovir) underline the need for new antiviral agents. In that perspective, Majewska et al. [5] focused on the in vitro inhibition of the replication of HSV-1 strains by IP and IFN- $\alpha$, and investigated whether there is an HSV-1 strain-specific pattern for the action of these compounds. The degree of inhibition of viral replication in vitro depended on the cell line and examined strain. Overall, increasing concentrations of IP $(50-400 \mu \mathrm{g} / \mathrm{mL})$ produced progressively growing inhibitory effects on HSV-1 replication in different cell lines, while a combination of IP and IFN- $\alpha$ displayed higher efficacy than either treatment alone [5].

The antiviral activity of IP was also studied in several in vivo experimental animal models of infection, such as influenza virus and herpes virus [20,31]. A marked increase in the survival rate of the animals was observed.

\section{THERAPEUTIC TRIALS}

To date, several therapeutic trials with IP have been designed for various infections and diseases, among which herpes infections, SSPE, HIV infections, AIDS and PGL, type B and C viral hepatitis, HPV infections and autoimmune diseases. The drug has been compared with placebo in several cases or versus other available treatments. The usual oral daily dosage of IP has ranged from 25 to $100 \mathrm{mg} / \mathrm{kg}$, totalling 1-6 g, in single or divided doses (4-6).

\section{Herpes Virus Infections}

Human HSV types 1 and 2, commonly known as HSV-1 and HSV-2, belong to the Alphaherpesvirinae subfamily of AIDS Herpesviridae family. HSV-1 usually causes orofacial infection, whereas HSV-2 is transmitted mainly sexually and is more often associated with genital infection. However, HSV-1 is an increasing cause of genital infection $[47,48]$. Both viruses can establish latent infection and there can be a recurrence affecting the same dermatome.

HSV-1, transmitted primarily by oral-oral contact, causes orolabial herpes ("cold sores") in those infected. HSV-1 infections occur principally during childhood and they are not eliminated from the human body. HSV-1 is the most common identified causal agent of sporadic encephalitis in children and adults. For 2012, the average worldwide prevalence of HSV-1 infection was estimated to be $67 \%$, while there was approximately a total of 118 million new infections reported [48].

The clinical presentation of HSV-2 infection is variable, and the majority of individuals are unaware that they are infected. In 2012, worldwide estimated prevalence and incidence of HSV-2 infection were 11.3 and $0.5 \%$, respectively. Affected people had an age range of 15-49 years, and more than half were women [49]. Although rare, infection in the neonate is associated with a high risk of severe morbidity and mortality [50].

Several double-blind, placebo-controlled studies of IP in herpes infections (labialis or genitalis) and other types of herpetic infections, such as zoster, have shown encouraging results which are summarized in Table 2.

In a recent study by You et al. [3], the efficacy and safety of oral IP was compared with acyclovir in the treatment of recurrent herpes labialis (RHL) and recurrent herpes genitalis (RHG). IP was as equally effective as acyclovir in treating RHL and RHG with significantly greater reduction of the short-term recurrence rate of herpes genitalis at 3-month follow-up. The main limitations of this study are the single follow-up at 3 months after treatment discontinuation, which cannot reflect the long-term 


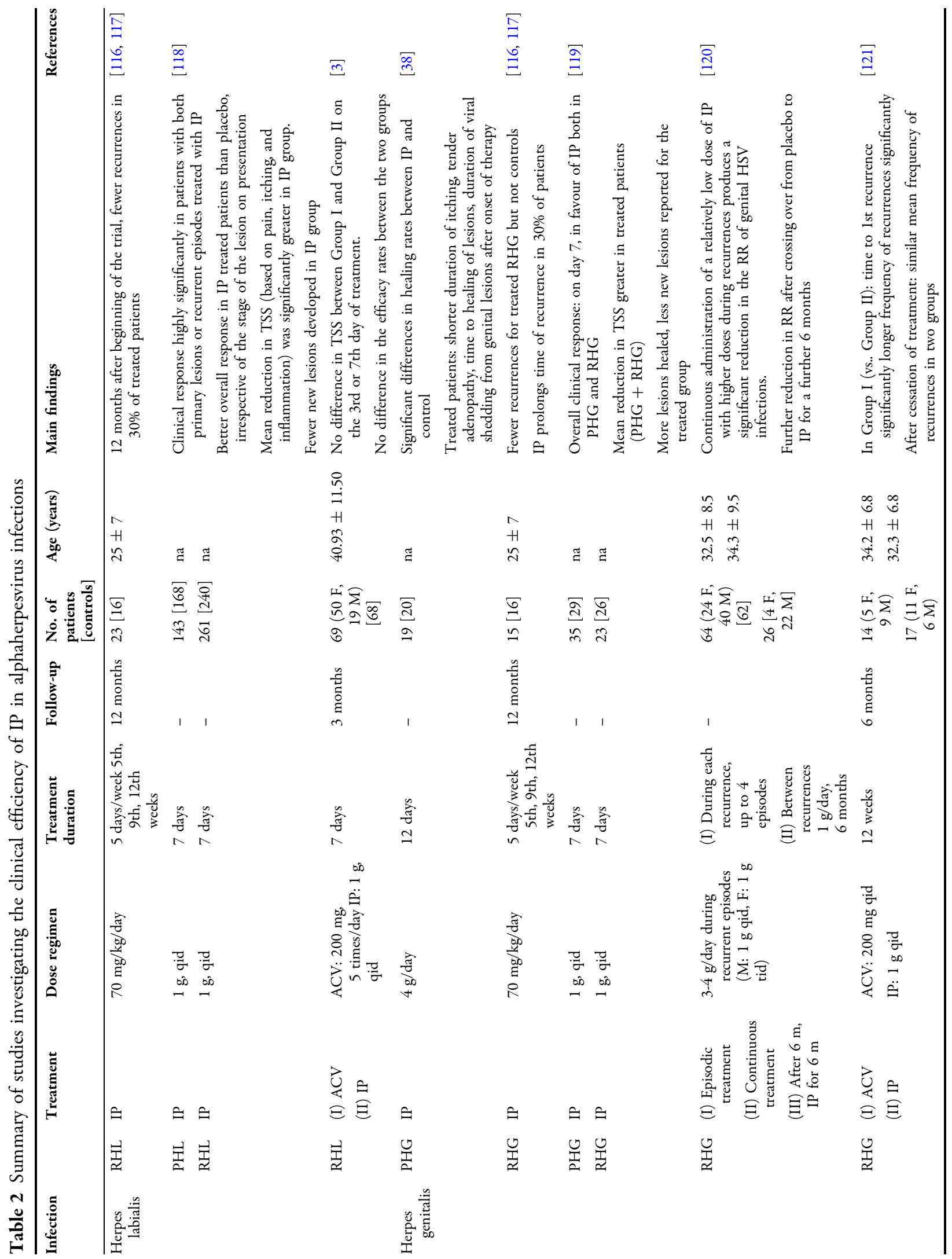




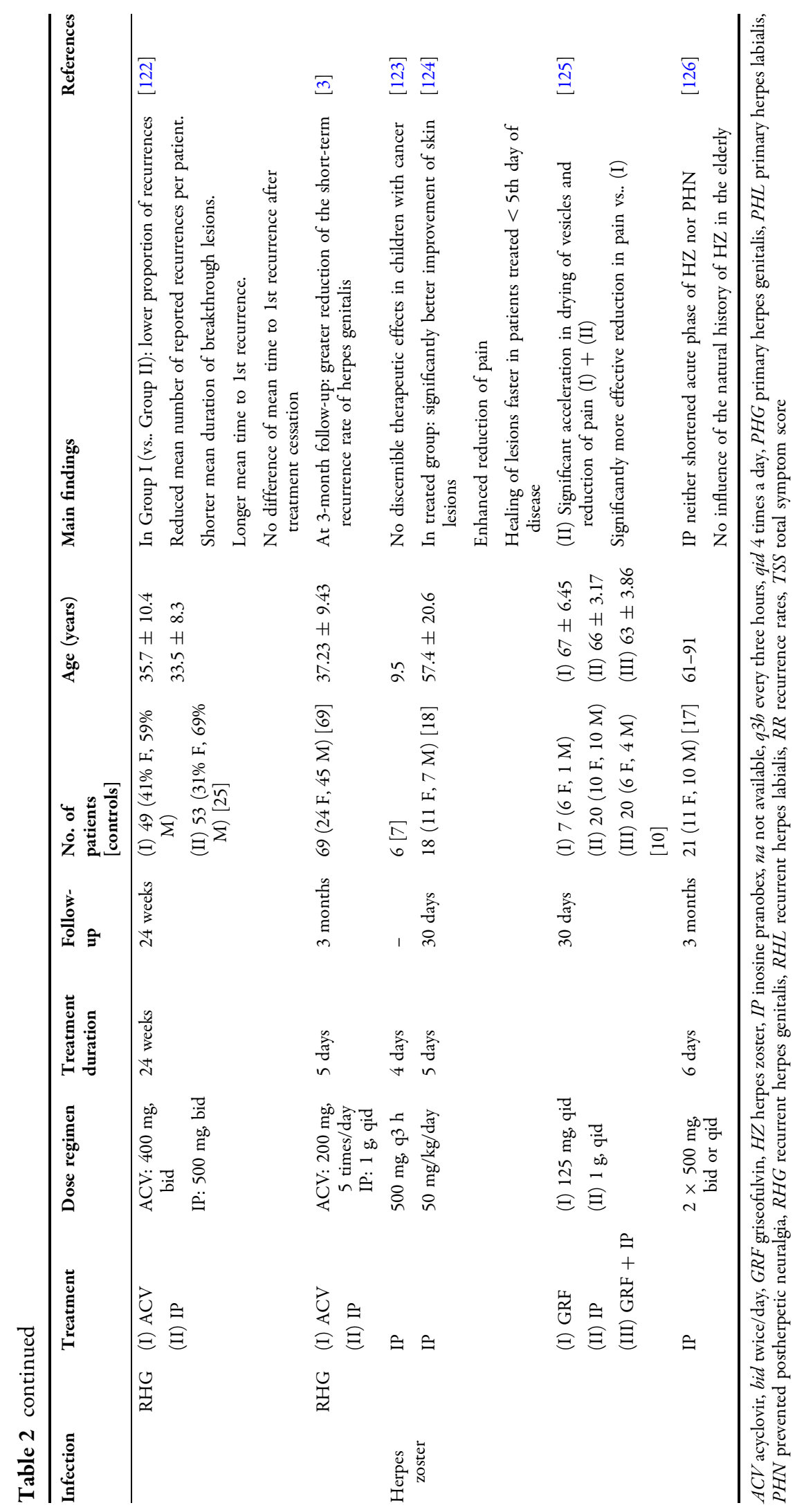


recurrence rate of RHG, and the lack of a control group with placebo treatment.

\section{Subacute Sclerosing Panencephalitis (SSPE)}

SSPE is a progressive and fatal neurodegenerative encephalitis owing to infection by the measles virus and its persistence in the cerebral nervous system. The prevalence of SSPE is inversely connected to measles vaccination and dependent on the patient's age. The estimated incidence of SSPE ranges from 4 to 11 cases per 100,000 cases of measles and involves mostly children younger than 5 years old [51, 52]. There is an average of $4-10$ years between the measles infection and the onset of the disorder, and prevalence is higher in males [53].

Several case reports have suggested that IP may provide beneficial therapeutic effects in patients with SSPE (reviewed in CampoliRichards et al. [31]; Gadoth [54]) contrary to Noetzel and Dodson [55] who reported unabated progression of cerebral pathology in a patient with SSPE despite continuous treatment with IP (70 mg/kg/day) and periods of considerable clinical improvement or stabilization. In another case report, improvement was observed after a combination of IFN- $\alpha$, ribavirin and IP therapy between 6 and 10 months; however, the patient suddenly deteriorated, and died [56].

Long-term studies, with or without a control group, have tested the impact of IP as a monotherapy in SSPE patients. Moreover, combined treatment regimens including IP were compared between them and against controls as to their effects in SSPE (Table 3). In most of the studies, it was suggested that the drug both increased survival and decreased neurological deficiencies [57-61].

The combination of IP and IFN- $\alpha$ appeared to be an effective treatment of SSPE (Table 3). In general, the beneficial effect of this combined regimen was observed in patients with slowly progressive SSPE, in contrast to patients with an acutely progressive course. Differences between studies could be attributed to the natural history of the disease, the disease stage at the time of IFN- $\alpha$ administration, the scope of each study, the limited number of patients, the use of historical controls, and the duration of treatment and of follow-up. Albeit with limited data, IFN- $\beta$ has been suggested as an alternative to IFN- $\alpha$, due to fewer side effects and an easier route of administration [62,63].

Various other kinds of drugs, such as amantadine, antivirals and DNA polymerase inhibitors [64-67], have been tested for treatment or to control disease progression. The efficacy of IFN- $\alpha$, amantadine, and IP in the treatment of SSPE was compared and all three drugs were found to be relatively effective in either ceasing or slowing down progression of the disease. Nonetheless, the efficacy of IP outweighed that of amantadine and IFN- $\alpha$ by an order of four and two, respectively [65]. Patients were also found to benefit from either the combination of IP with IFN and lamivudine [67] or with IFN and antivirals [66].

The results from a multinational survey on actual diagnostics and treatment of SSPE, incorporating the experience of contributing physicians, revealed that IP monotherapy and combined oral IP plus ribavirin were applied frequently, as opposed to any combinations of IP with the following: IFN- $\alpha$ either subcutaneously or via an implanted pump, ribavirin plus IFN- $\alpha$ via an implanted pump, intraventricular IFN- $\alpha$ plus ribavirin, amantadine, and subcutaneous IFN- $\beta$ [68]. Clinical and demographics characteristics along with commonly applied treatments were reviewed in a retrospective study including 43 children. IP was apparently the mainstay treatment either as a monotherapy (51\% of patients) or in combination with IFN- $\beta$ (4.7\%) [69].

No cure exists for SSPE, which can only be prevented by a timely vaccination against measles. Nevertheless, the efficacy of IP on disease progression and patient survival rate, especially at early stages of SSPE, is evident by the obtained results (Table 3). Combined administration of IP and interferons has been supported by the majority of studies to achieve clinical improvement and prolonged survival. It should be noted that treatment shorter than 2 months was not found to be effective, and 


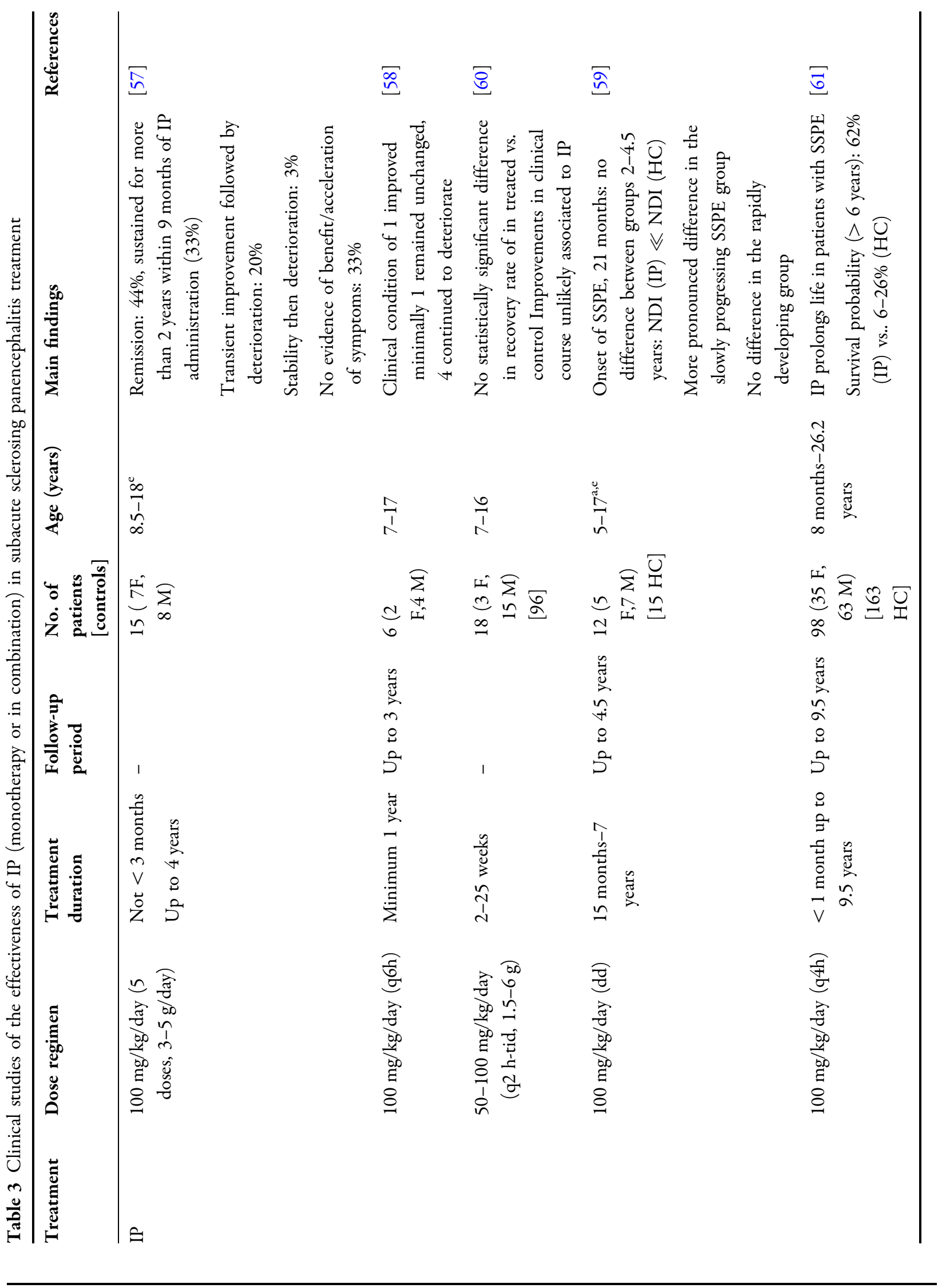




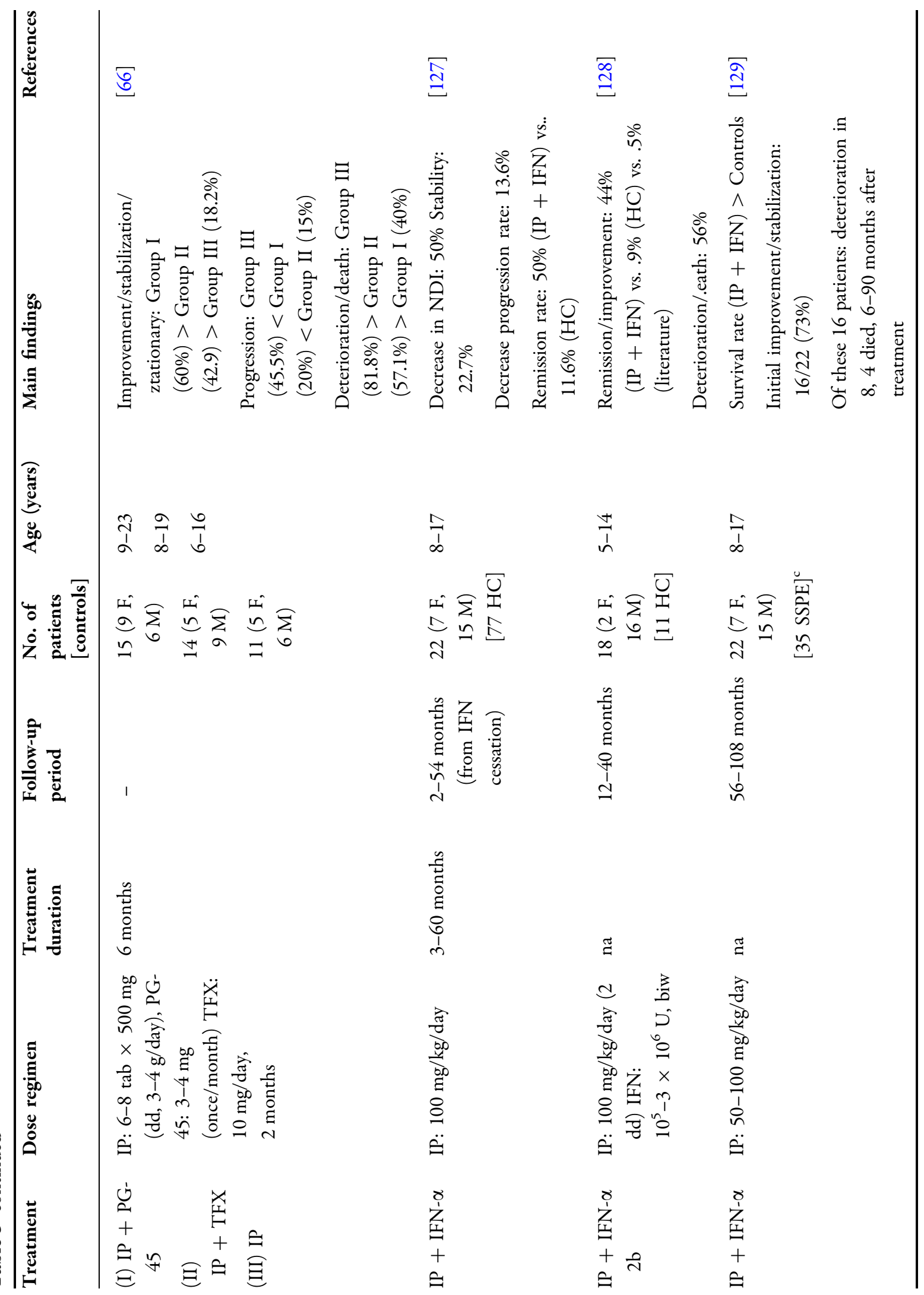




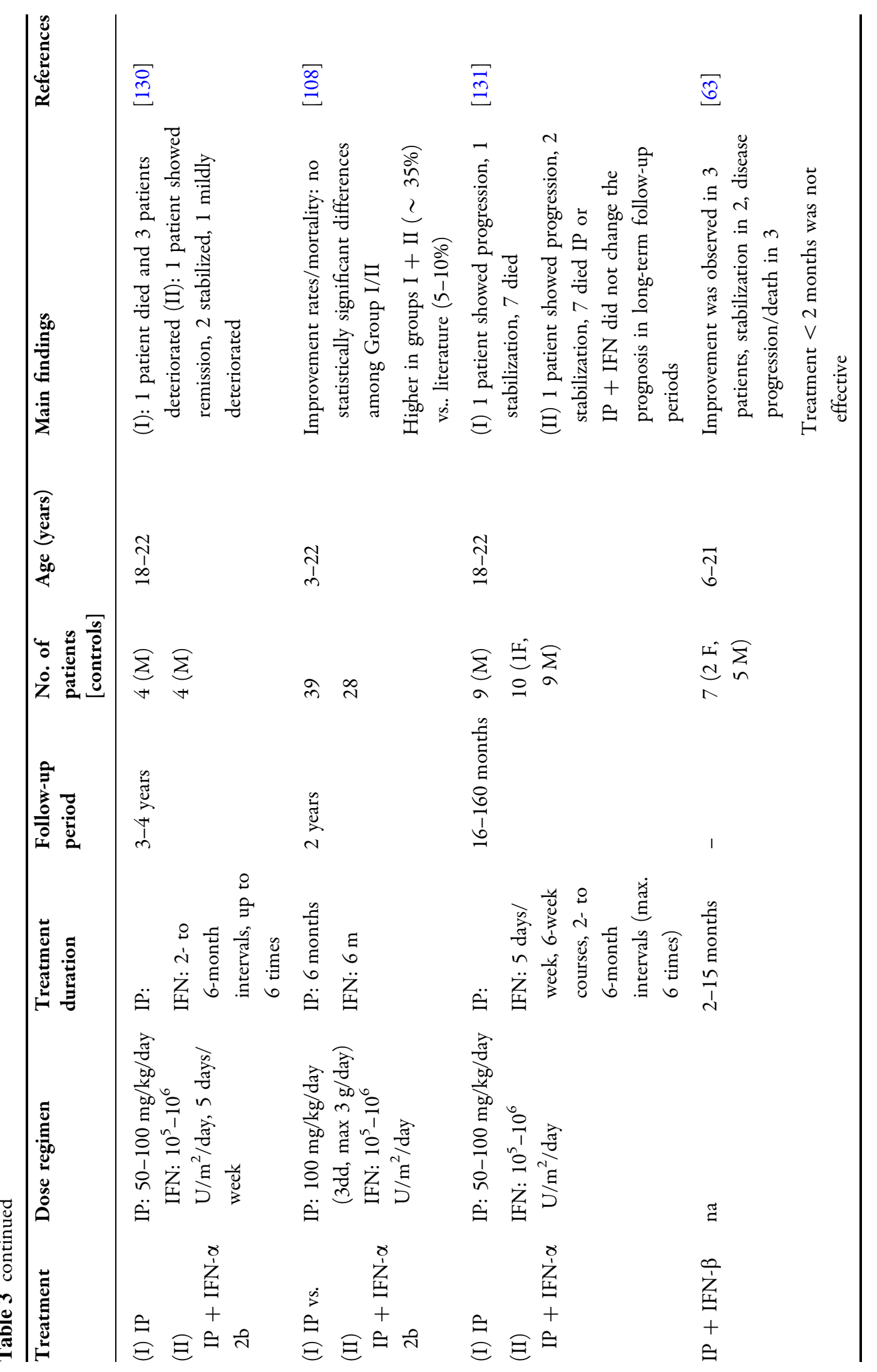




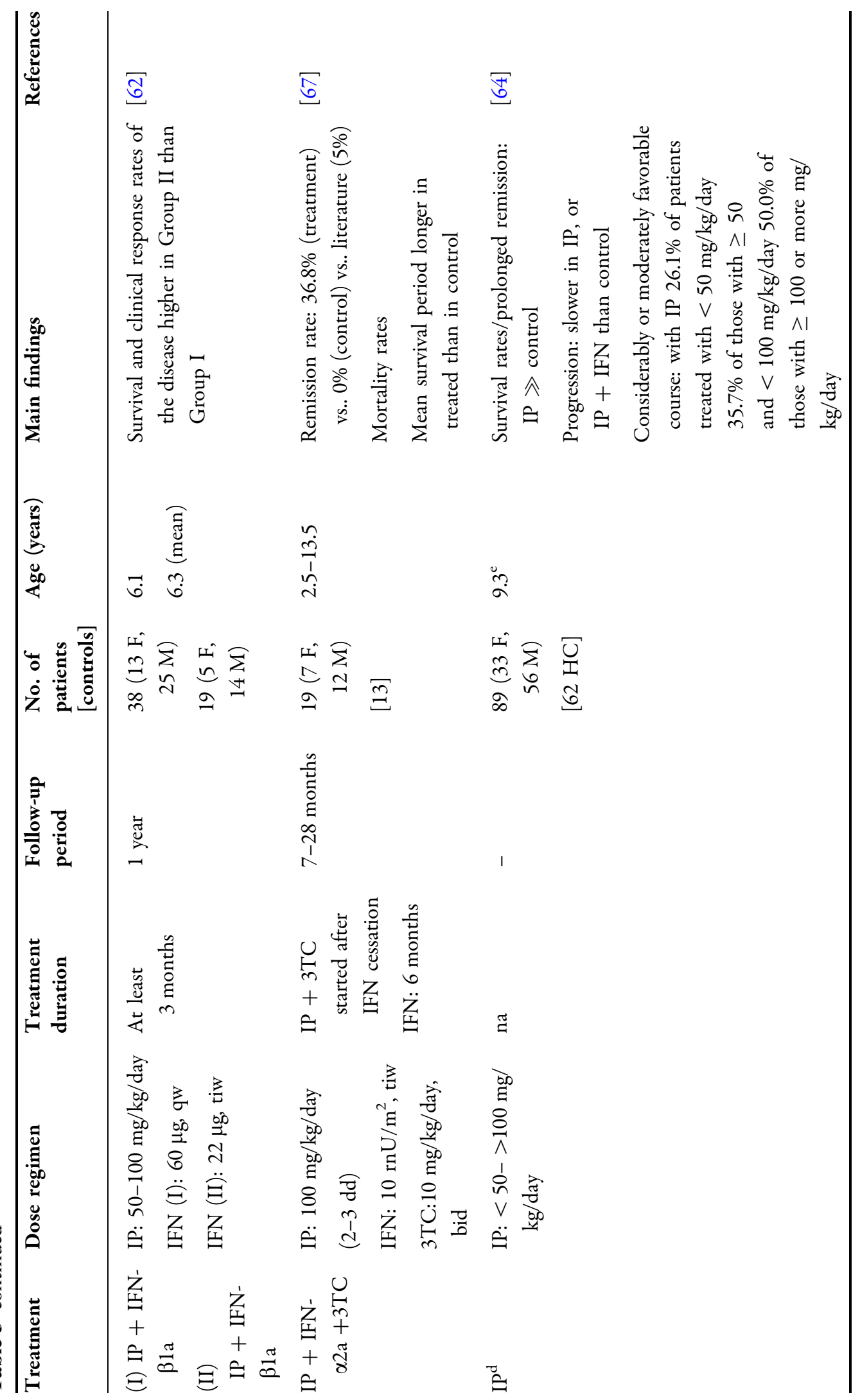




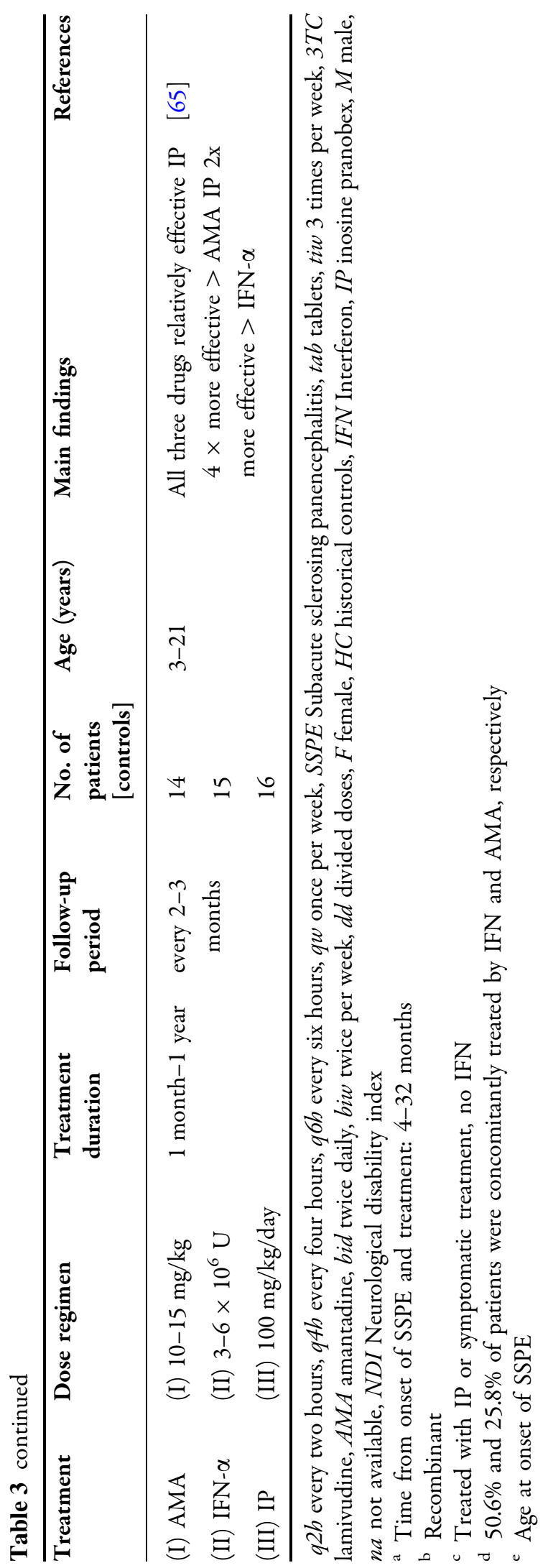

administration of relevant drugs should be continued even after apparent remission [65].

\section{Human Papilloma Virus Infections}

In early studies, comparing the efficacy of IP to conventional treatments (podophyllin, cryotherapy, electrocautery, $\mathrm{CO}_{2}$ laser and surgery), a combined use of oral IP plus conventional non-surgical treatment of genital warts was found to produce more increased cure rates that conventional treatment alone [70, 71]. The authors concluded that the advantage of oral or topical treatment over hospitalisation and anaesthesia make IP a valid therapy. However, these studies had certain limitations, such as lack of placebo controls. In a multicentre, prospective, randomised, placebo-controlled study by Davidson-Parker et al. [72] it was suggested that IP may be worth considering as adjunct to conventional treatment (primary podophyllin or trichloroacetic acid) of patients with refractory genital warts.

A randomized, double-blind, placebo-controlled study demonstrated a significant pharmacological activity of oral IP in subclinical HPV infection of the vulva [73]. Moreover, involvement of HPV in chronic vulvodynia is suspected, based on identifications of acetowhite vulval lesions. Although limited data exists on this topic, it was suggested that oral IP could also serve as a non-invasive alternative for the treatment of young women with chronic vulvodynia [74].

The efficiency and toxicity of IP has been investigated in the combined treatment of patients infected with HPV 16 and 18, manifesting epithelial dysplasia and preinvasive cancer of the cervix uteri [75]. Following a course of IP treatment, HPV 16 and 18 were undetectable in $77.8 \%$ and $50 \%$ of treated patients, respectively. A second or third course of treatment was required for only a small proportion of patients.

Of the 17 treated individuals registered in a randomised, placebo-controlled study on the efficacy and safety of IP in the treatment of cervical condylomata acuminata, four responded to the treatment completely, seven 
responded partially and six did not respond at all. The therapeutic difference between treated women and placebo group was statistically significant. No recurrences were observed during the 12-month follow up in the complete responders. Adverse effects were mild and resolved upon completion of therapy [76].

An open trial compared the results of combined therapy using surgery and IP in a group of 25 patients with oral HPV-positive proliferative verrucous leucoplakia (PVL) against a group of 25 patients that underwent only surgery. Six months postoperatively there was a significant difference, with 18 recurrences in the patients treated by surgery alone compared to only two recurrences in those treated also with IP. Eighteen months postoperatively there were no further recurrences in the patients treated by surgery alone but two new recurrences in those treated with IP. Overall, by 18 months followup, there were 18 recurrences in the surgerytreated group, and only four in the IP group. The use of this antiviral agent appeared to offer a significant enhancement to the surgical management of PVL [77].

Studies of the effect of IP in patients with HPV infections are summarised in Table 4. Considerable efficacy with insignificant and reversible adverse effects and with low rate of recurrences is supported, hence IP may represent an efficacious and safe alternative therapy for HPV infections.

\section{Influenza and Rhinovirus Infections}

While treatment with IP in a total daily dose of $6 \mathrm{~g}$ had no statistically significant effect on the clinical course and serology of experimental infection due to rhinovirus 44 or rhinovirus 32 [78], a total daily dose of $4 \mathrm{~g}$ effected a significantly lower incidence and severity of rhinovirus 21 infection (vs. placebo) [79].

A study in volunteers challenged intranasally with influenza virus has shown significantly reduced symptomatology for the treated group [80]. Additively to them, the efficacy and safety of IP have been supported in a recent Phase 4 randomized, placebo-controlled, double-blind study [81] in subjects with clinically diagnosed influenza-like illness, including subjects with laboratory-confirmed acute respiratory viral infections due to influenza A or B virus, RSV, adenovirus, or parainfluenza virus 1 or 3 [81]. The study results indicate the safety of IP for the treatment of subjects with laboratory-confirmed acute respiratory viral infections and confirm the efficacy of IP versus placebo in healthy nonobese subjects less than 50 years of age with clinically diagnosed influenza-like illnesses [81]. Statistically significant differences in time to resolution of influenza-like symptoms were obtained for the IP subgroups containing subjects less than 50 years of age who were without related ongoing disease and subjects of less than 50 years of age who were non-obese.

\section{Type B and C Viral Hepatitis}

IP was considered ineffective for patients in the acute phase of classical acute viral hepatitis [82]. In a double-blind, placebo-controlled study, 30 patients with HBsAg-positive acute hepatitis were administered $6 \mathrm{~g}$ /day of IP for a mean duration of 28 days [83]. Treatment and placebo groups were comparable as to clinical symptoms and signs, and hematological and immunological parameters. After 4 weeks of therapy, the IP group had significantly less asthenia, anorexia and splenomegaly, lower total bilirubin, transferases and alkaline phosphatase concentrations, and greater well-being. There was no statistically significant difference in abdominal malaise, nausea or hepatomegaly. Within 90 days from therapy initiation, a significantly greater number of treated patients were HBsAgnegative.

Immunomodulation therapy for patients with hepatitis $C$ virus infection has been addressed only in individual cases or small groups of people $[84,85]$. Use of IP, as monotherapy or in combination with ribavirin, had no impact on viral load. Similarly, the increase in levels of alanine aminotransferase were not considered important. However, normalization of alanine aminotransferase levels was observed in patients non-responsive to IFN treatment [85]. In addition, concomitant use of IP with ribavirin improved disease severity and 


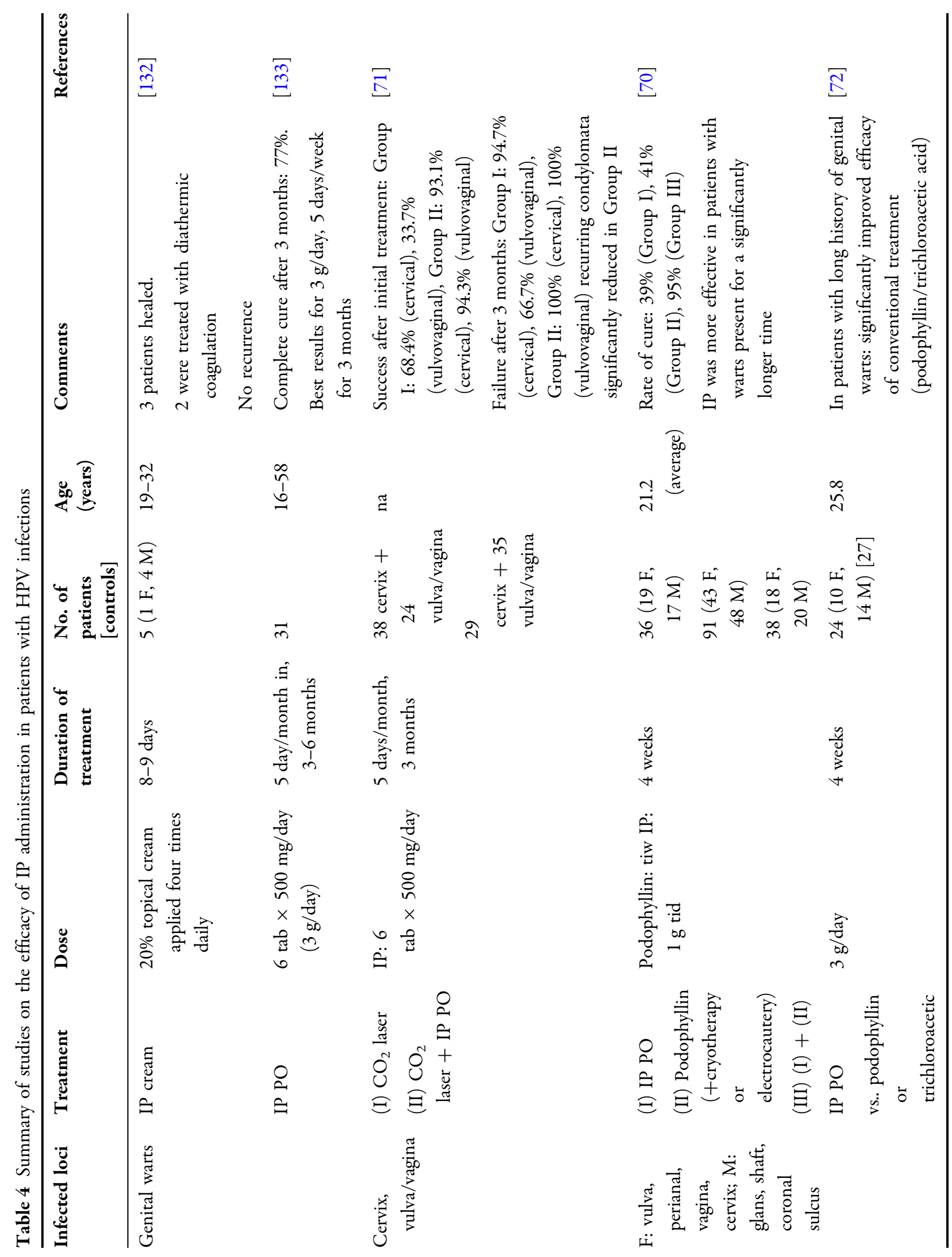




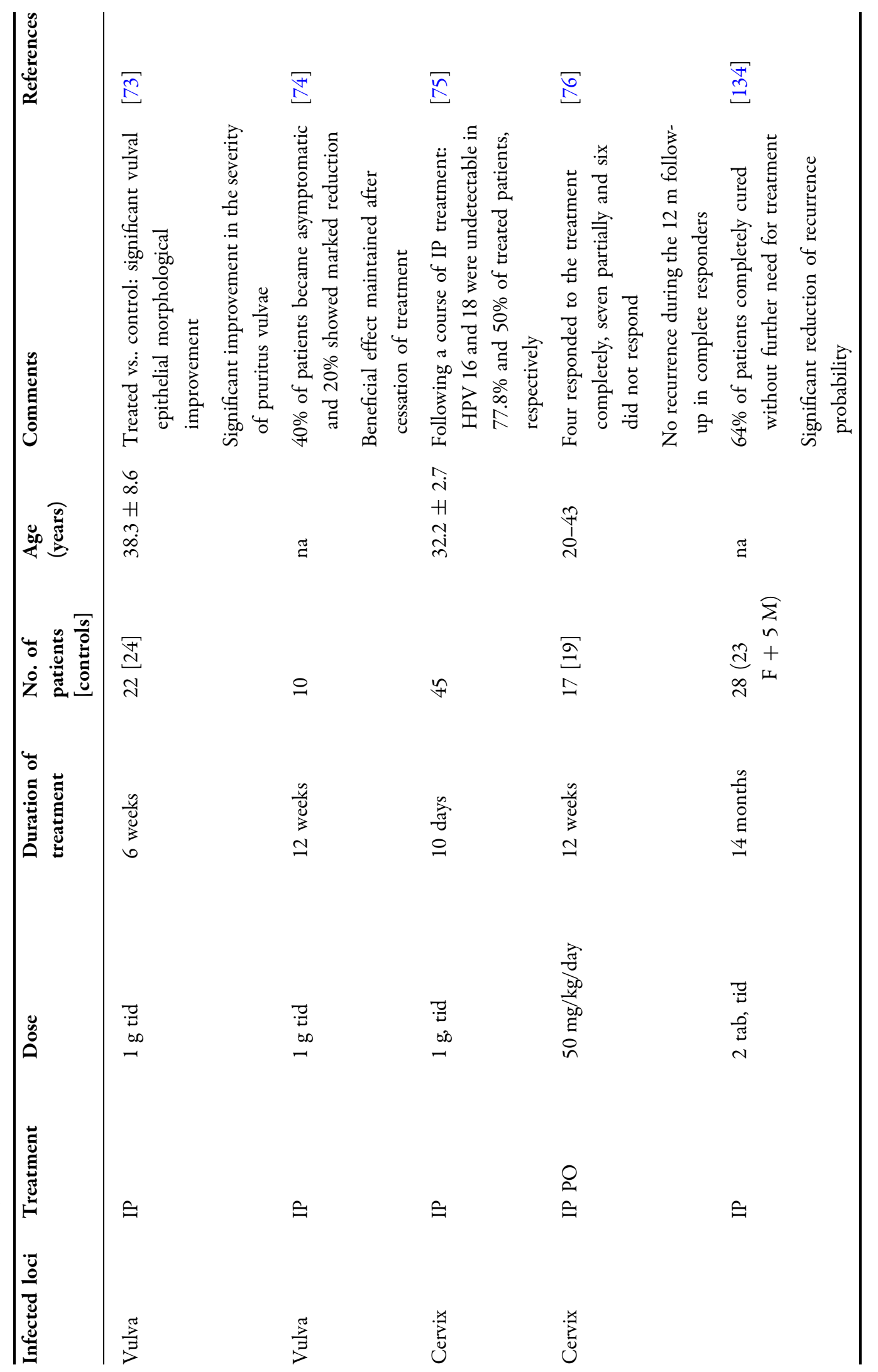




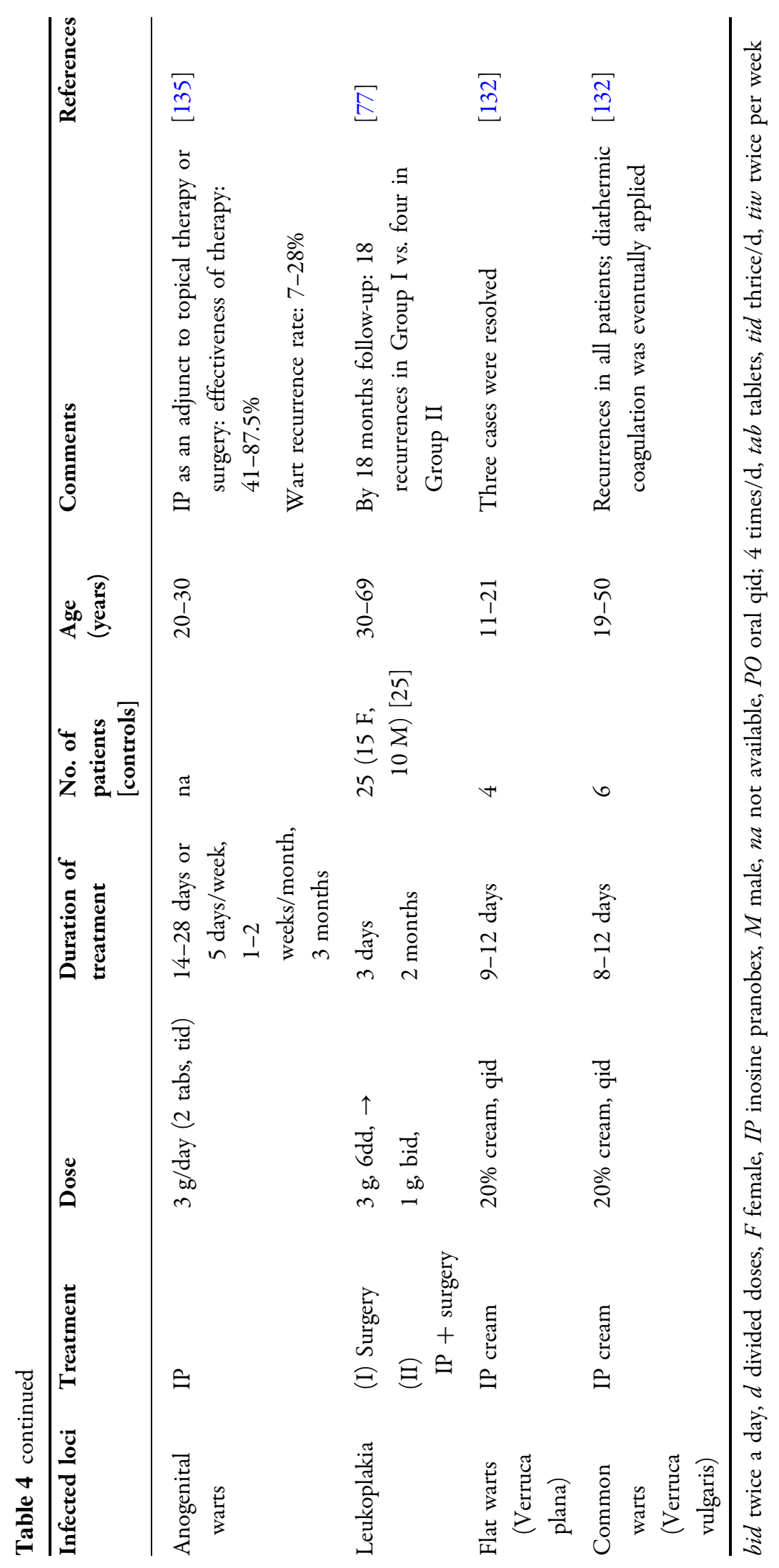


liver inflammation, evidenced by a reduction in the levels of the IFN- $\gamma$-inducible protein 10 [84]. If similar results are obtained in the future in controlled studies with larger numbers of patients, the beneficial role of IP, especially in the case of patients non-responsive to mainstay treatments, could be established.

\section{Persistent Generalised Lymphadenopathy, HIV, and Acquired Immunodeficiency Syndrome}

Evidence from early studies suggested that IP may improve some of the clinical symptoms associated with PGL in immunosuppressed males. In a placebo-controlled study in immunologically suppressed homosexual males with PGL, a total oral daily dosage of $3 \mathrm{~g}$ IP administered for 28 days also appeared to stimulate positive clinical effects $[18,86]$. A greater percentage of drug-treated than placebo patients had an improvement in qualitatively assessed clinical symptoms, i.e., well-being, increased appetite, weight gain, night sweats, fever, skin rashes and lymph node pain.

The efficacy and safety of IP in patients infected with HIV and with no manifestation of AIDS was investigated within a placebo-controlled study, including a total of 831 male and female patients. Use of IP was found to be safe, as no serious side effects were reported. In addition, an effective delay in the progression to AIDS has been observed in the treated group [87]. Kovacs et al. [88] investigated the mechanism through which IP prevents Pneumocystis jiroveci (formerly $P$. carinii) pneumonia in patients infected with HIV, thus decreasing progression to AIDS. The plausible explanation provided was inhibition of the metabolism of $P$. jiroveci, in particular of dihydropteroate synthetase by p-acetamidobenzoic acid, one of IP's components [88].

Besides the positive results emerging from these studies, showing that IP can both improve clinical symptoms and delay progression of HIV infection, it has also been described that its concomitant administration with zidovudine may have advantageous effects in HIV-infected patients [89].

\section{Autoimmune Diseases}

Positive immunomodulating effects of IP have been demonstrated in several studies on patients with autoimmune diseases, such as alopecia, rheumatoid arthritis or aphthous stomatitis, but further investigation is warranted to determine the efficacy of IP in the treatment of specific autoimmune diseases. In therapeutic studies, positive clinical effects of IP, at doses of $25-50 \mathrm{mg} / \mathrm{kg}$ daily (1.5-3 g), have been reported in the majority of treated patients with aphthous stomatitis [41] and alopecia $[39,40,90]$.

In a randomized, placebo-controlled, double-blind study in patients with rheumatoid arthritis, a daily dose of $3 \mathrm{~g}$ IP failed to produce any positive therapeutic results [4]. Notably, the same treatment regimen has been found to be beneficial in terms of morning stiffness, tender joints, proximal interphalangeal joint circumference, sedimentation rate and fibrinogen level [91-93]. Consequently, use of IP as a secondline activity in rheumatoid arthritis would need more supportive evidence.

\section{Chronic Fatigue Syndrome}

Chronic fatigue syndrome (CFS) is characterised by symptoms such as severe fatigue, exercise intolerance, myalgia, cognitive deficit, dizziness and problems in sleep, thinking and concentration. It is most common in people between 40 and 60 years old, but it can also affect children, adolescents, and adults of all ages, with women being more susceptible. Its pathogenicity has not been yet defined, and it remains undiagnosed in approximately $90 \%$ of affected people. It is speculated that changes in the immune system, such as chronic production of cytokines, decreased NK activity and differences in markers of T-cell activation, may contribute to the onset of CFS. There is no cure or established treatment for CFS, and healthcare professionals are mainly trying to cure the symptoms rather the disease itself [94].

The safety and efficacy of IP in CFS were investigated in a single-blind, placebo-controlled study of 16 CFS patients, with a mean 
age of 45.6 years [17]. Ten patients were randomly assigned to a regimen of IP for 12 weeks, consisting of $3 \mathrm{~g} /$ day on the odd weeks and $1 \mathrm{~g}$ /day on the even weeks, and six patients received methylcellulose placebo tablets. Following the 12 weeks of treatment, patients from both the treatment and the placebo groups received IP for 16 more weeks. Immune measures as well as responses of the patients to three tests, i.e., the Activities of Daily Living Questionnaire, the Cognitive Deficit Subset of the Symptom Checklist Questionnaire and the Karnofsky Performance Score, were evaluated.

Of the ten patients treated initially with IP, six reported improvement in their symptoms (improved group) and the median percentage reduction in cognitive symptoms for this group was $16 \%$. The results from this study suggest that patients with CFS could benefit from treatment with IP. Nevertheless, further studies are warranted, with an adequate sample size and a longer follow-up period, in order to extract firm conclusions as to the efficacy of IP.

\section{Multiple Sclerosis}

Multiple sclerosis (MS) is one of the most common neurological disorders and causes of disability in young adults. Most people with MS have a normal or near-normal life expectancy. It may happen that some people with MS will experience little disability during their lifetime; nonetheless, up to $60 \%$ are no longer fully ambulatory 20 years after onset, with major implications for their quality of life. In rare cases, MS can be terminal. Globally, the median estimated prevalence of MS is 30 per 100,000, with the greatest prevalence in Europe (80 per 100,000), followed by the Eastern Mediterranean (14.9), the Americas (8.3), the Western Pacific (5), South-East Asia (2.8) and Africa (0.3). MS is more frequent in high-income countries (89 per 100,000). The global median estimated incidence of MS is 2.5 per 100000 per year, with Europe ranking first (3.8 per 100,000), followed by the Eastern Mediterranean (2), the Americas (1.5), and the Western Pacific [95].

Use of IP in the treatment of MS has been investigated in several studies (see Hommes and
Comi [96] and references therein). Significant beneficial changes were observed in patients with relapsing-remitting MS treated with IP, in regard to the mean annual relapse rate, the Kurtzke Disability Status Scale values, and the mean period of standard corticosteroid therapy [97]. In contrast to that, no significant difference in the clinical course of the disease between IP-treated patients and the control group were observed in 11 patients over a treatment period of 60 days [98].

The immunological and clinical beneficial effects of IP therapy in patients with exacerbating remitting MS were supported in the study by Pompidou et al. [99]; however, no firm conclusions could be drawn as to the long-term effectiveness of IP. A total of 52 patients with relapsing-remitting and relapsing-progressing MS were included in a double-blind, randomized, and placebo-controlled study, during which they were administered $3 \mathrm{~g}$ of IP or placebo for 2 years following a single, pulsed, intravenous administration of methylprednisolone. No benefit was demonstrated in the relapse rate, yet the expanded disability status scale and ambulation index show increased favor for the IP group, especially in the relapsing-remitting MS patients [100].

It is evident that outcomes from different studies are conflicting. Methodological bias makes it difficult to evaluate a potential benefit. There were major differences between the dosages, treatment regimens, patient selection and number, follow-up, and errors in randomization of patients in the treated and placebo groups.

\section{Other Diseases and Infections}

Worldwide, tuberculosis (TB) is one of the top ten causes of death, and it strikingly ranks above HIV/AIDS. The global incidence of TB for 2017 was approximately 10 million. Prevalence is higher in male adults. In 2017, the proportion of people who died from TB was $16 \%$. Among HIV-negative and HIV-positive people, TB is estimated to have caused 1.3 and 0.3 million deaths, respectively. About $23 \%$ of the world's population is estimated to have a latent TB 
infection [101] which, together with the length of treatment, malnutrition and weak immunity, are the major obstacles in controlling the TB epidemic [102]. The bacille Calmette-Guérin vaccine has been shown to prevent severe forms of TB in children, yet no such vaccine exists for adults, either before or after exposure to TB infection. The currently recommended treatment for cases of drug-susceptible $\mathrm{TB}$ is a 6-month regimen of four first-line drugs, i.e., isoniazid, rifampicin, ethambutol and pyrazinamide. However, drug-resistant TB continues to be a public health crisis. Approximately 600,000 people worldwide in 2017 developed TB resistant to rifampicin, the most effective first-line drug, and, of these, $82 \%$ had multidrug-resistant TB [101].

The efficacy of IP against Mycobacterium tuberculosis has not so far been tested. IP enhances TNF- $\alpha$ and IFN- $\gamma$ (Th1 cytokines), stimulates T-lymphocyte differentiation into T-cytotoxic cells and T-helper cells and potentiates lymphoproliferation, both in vitro and in vivo. This resembles crucial responses of the host immune system during early stages of $M$. tuberculosis infection used to evade the pathogen. Based on this, Mishra et al. [103] suggested that the use of IP as an adjunct anti-tuberculosis chemotherapy should be considered, as potentiation of innate immunity by IP in combination with the direct inhibitory activity of the anti-TB drugs could help fight the infection while at the same time allowing for the reduction of drug doses and side effects [103]. Mishra et al. [103] have also outlined a strategy for evaluating repurposed IP for the treatment of tuberculosis.

Conclusions from a randomized, doubleblind study on 22 children, aged $2.7-16.8$ years with early dengue infection, suggest that IP could be used along with standard approved fluid and anti-pyretic therapy [104].

In vivo studies of the effect of IP on Echinococcus multilocularis and E. granulosus metacestodes (Cestoda), the causal agents of hydatid disease, have been performed, using jirds and mice as experimental hosts. Short- and long-term treatments with different doses (ranging from 0.5 to $4 \mathrm{~g} / \mathrm{kg}$ ) were tested. Marked ultrastructural damage with metabolic perturbations was observed in a dose-dependent mode
$[105,106]$. Evidence for direct interaction of IP with Echinococcus has been provided by Lawton et al. [107].

\section{CONCLUSIONS}

Inosine pranobex is a synthetic agent with immunomodulating and antiviral properties currently indicated for the treatment of various viral diseases, among which SSPE, HSV, and varicella infections, respiratory infections, influenza, and viral hepatitis, and as an adjuvant therapy for HPV infections.

In almost 50 years since its initial authorization, IP has been assessed extensively in herpes simplex genitalis and labialis and encouraging clinical results have been reported. The drug has been found to be clinically useful in SSPE, either as a monotherapy or as part of a combination regimen, usually with IFN- $\alpha$. In the treatment of genital warts, the combined use of oral IP and conventional non-surgical treatment has resulted in greatly increased cure rates versus the rates for conventional treatment alone. Individual double-blind, placebocontrolled studies in immunologically depressed homosexual men with persistent generalized lymphadenopathy treated with IP also had a positive outcome. Statistically significant clinical benefits of the use of IP have been reported for patients with type B viral hepatitis. The efficacy and safety of IP have also been supported in patients with influenza and influenza like illnesses.

In various cases, the positive effects from the administration of IP, either in animal models or humans, have been time-limited or there was a recurrence of symptoms. Consequently, treatment with IP should be repeated and be longterm, especially in some chronic infections [36, 42, 53, 108].

In recent years, the increased understanding of the antiviral immune mechanisms, the limited number of approved drugs for medical use against HSV and the occurrence of drug-resistant HSV strains have encouraged even more the administration of IP as part of a combination therapy for HSV patients, especially those infected with viral strains resistant to currently 
known antiviral drugs. Likewise, synergistic use of IP together with other agents, such as IFN- $\beta$ and lamivudine, can help achieve enhanced clinical responses and survival rates of SSPE patients, but further investigation is warranted. Recently, limited data indicate that the use of IP may be extended to other HPV-related diseases (e.g., leukoplakia, cervix dysplasia, etc.). Emerging data concerning diseases for which no treatment exists and IP has been found or speculated to have positive effects (e.g., chronic fatigue syndrome, multiple sclerosis, tuberculosis, etc.), should attract more attention and be further investigated. Although TB is curable, treatment protocols are complex and lengthy, hence difficult to adhere to. The emergence of multidrug-resistant $M$. tuberculosis strains and the association of TB with HIV have further exacerbated the problem [102]. In this regard, the repurposing and revival of existing drugs, such as IP, which are currently in use for other diseases could be an excellent strategy to meet the urgent requirement of new drugs [103].

The use of a drug with a safety profile such as that of IP in fatal and/or debilitating diseases, such as SSPE or AIDS, or even in painful, recurring and/or psychologically traumatic diseases, such as herpes and HPV infections, is greatly needed and tempting but challenging at the same time. To fully support the value of IP, placebo-controlled, dose-response studies, welldesigned and reported in terms of, e.g., target populations, treatment duration, and efficacy markers are warranted. Additional efforts to investigate the direct antiviral activity of IP and correlate it with the clinical outcome following treatment would help to further elucidate the mechanism of action of IP. In such a manner, the safety and quality of life of patients will be better served, the place of the drug in therapy of various diseases will be firmly established, and possibly new indications for IP will be unveiled.

\section{ACKNOWLEDGEMENTS}

Funding. Preparation of this article, the article processing charges and the open access fee were supported by Ewopharma International. All authors had full access to the articles reviewed in this manuscript and take complete responsibility for the integrity and accuracy of this manuscript.

Medical Writing, Editorial, and Other Assistance. We would like to thank Dr Eva Salapova, Dr Sonja Stojkovic Buric, Dr Anja Petrovic and Mgr. Lukas Dusek for carefully reviewing our manuscript and for their critical comments.

Authorship. All named authors meet the International Committee of Medical Journal Editors (ICMJE) criteria for authorship for this article, take responsibility for the integrity of the work as a whole, and have given their approval for this version to be published.

Disclosures. Jiri Sliva has nothing to disclose. Chrysoula N. Pantzartzi has an ongoing collaboration with Ewopharma International. Martin Votava has an ongoing collaboration with Ewopharma International.

Compliance with Ethics Guidelines. This article is based on previously conducted studies and does not contain any studies with human participants or animals performed by any of the authors.

Open Access. This article is distributed under the terms of the Creative Commons Attribution-NonCommercial 4.0 International License (http://creativecommons.org/licenses/ by-nc/4.0/), which permits any noncommercial use, distribution, and reproduction in any medium, provided you give appropriate credit to the original author(s) and the source, provide a link to the Creative Commons license, and indicate if changes were made.

\section{REFERENCES}

1. Wybran J, Appelboom T. Isoprinosine (inosiplex): immunological and clinical effects. Immunomodulation. Boston, MA: Springer; 1984. p. 363-74. 
2. Masihi KN. C7 Anti-infective activity of immunomodulators. Principles of immunopharmacology. Basel: Birkhäuser; 2011. p. 411-35.

3. You Y, Wang L, Li Y, Wang Q, Cao S, Tu Y, et al. Multicenter randomized study of inosine pranobex versus acyclovir in the treatment of recurrent herpes labialis and recurrent herpes genitalis in Chinese patients. J Dermatol. 2015;42(6):596-601. https://doi.org/10.1111/1346-8138.12845.

4. Brzeski M, Madhok R, Hunter JA, Capel HA. Randomised, double blind, placebo controlled trial of inosine pranobex in rheumatoid arthritis. Ann Rheum Dis. 1990;49:293-5.

5. Majewska A, Lasek W, Janyst M, Mlynarczyk G. In vitro inhibition of HHV-1 replication by inosine pranobex and interferon- $\alpha$. Acta Pol Pharm. 2016;73(3):637-44.

6. Tobolska S, Terpilowska S, Jaroszewski J, Siwicki AK. Genotoxicity and mutagenicity of inosine pranobex. J Vet Res. 2018;62(2):207-13. https://doi. org/10.2478/jvetres-2018-0030.

7. Tobólska S, Terpiłowska S, Jaroszewski J, Siwicki AK. Influence of inosine pranobex on cell viability in normal fibroblasts and liver cancer cells. J Vet Res. 2018;62(2):215-20. https://doi.org/10.2478/jvetres2018-0031.

8. Hadden J, Wybran J, editors. Immunopotentiators II Isoprinosine, NPT 15392 and Azimexone: modulators of lymphocyte and macrophage development and function. Advances in Immunopharmacology: Proceedings of the First International Conference on Immunopharmacology; 1981: Elsevier.

9. Petrova M, Jelev D, Ivanova A, Krastev Z. Isoprinosine affects serum cytokine levels in healthy adults. J Interferon Cytokine Res. 2010;30(4):223-8. https://doi.org/10.1089/jir.2009.0057.

10. Lasek W, Janyst M, Wolny R, Zapala L, Bocian K, Drela N. Immunomodulatory effects of inosine pranobex on cytokine production by human lymphocytes. Acta Pharm. 2015;65(2):171-80. https:// doi.org/10.1515/acph-2015-0015.

11. Milano S, Dieli M, Millott S, Miceli MD, Maltese E, Cillari E. Effect of isoprinosine on IL-2, IFN-gamma and IL-4 production in vivo and in vitro. Int J Immunopharmacol. 1991;13(7):1013-8.

12. Tsang KY, Pan JF, Swanger DL, Fudenberg HH. In vitro restoration of immune responses in aging humans by isoprinosine. Int J Immunopharmacol. 1985;7(2):199-206. https://doi.org/10.1016/01920561(85)90027-X.
13. Tsang KY, Fudenberg HH, Pan JF, Gnagy MJ, Bristow CB. An in vitro study on the effects of isoprinosine on immune responses in cancer patients. Int J Immunopharmacol. 1983;5(6):481-90.

14. Sabat R, Grutz G, Warszawska K, Kirsch S, Witte E, Wolk K, et al. Biology of interleukin-10. Cytokine Growth Factor Rev. 2010;21(5):331-44. https://doi. org/10.1016/j.cytogfr.2010.09.002.

15. Ahmed RS, Newman AS, O'Daly J, Duffy S, Grafton $\mathrm{G}$, Brady CA, et al. Inosine acedoben dimepranol promotes an early and sustained increase in the natural killer cell component of circulating lymphocytes: a clinical trial supporting anti-viral indications. Int Immunopharmacol. 2017;42:108-14. https://doi.org/10.1016/j.intimp.2016.11.023.

16. Balestrino C, Montesoro E, Nocera A, Ferrarini M, Hoffman T. Augmentation of human peripheral blood natural killer activity by methisoprinol. J Biol Response Modif. 1983;2(6):577-85.

17. Diaz-Mitoma F, Turgonyi E, Kumar A, Lim W, Larocque L, Hyde BM. Clinical improvement in chronic fatigue syndrome is associated with enhanced natural killer cell-mediated cytotoxicity: the results of a pilot study with Isoprinosine ${ }^{\circledR}$. J Chronic Fatigue Syndr. 2003;11(2):71-95.

18. Bekesi JG, Tsang PH, Wallace JI, Roboz JP. Immunorestorative properties of isoprinosine in the treatment of patients at high risk of developing ARC or AIDS. J Clin Lab Immunol. 1987;24(4):155-61.

19. Hersey P, Edwards A. Effect of isoprinosine on natural killer cell activity of blood mononuclear cells in vitro and in vivo. Int $\mathrm{J}$ Immunopharmacol. 1984;6(4):315-20.

20. Ohnishi H, Kosuzume H, Inaba $H$, Ohkura M, Shimada S, Suzuki Y. The immunomodulatory action of inosiplex in relation to its effects in experimental viral infections. Int $\mathrm{J}$ Immunopharmacol. 1983;5(3):181-96.

21. De Simone C, Ricca D, Sorice F. In vitro influence of methisoprinol on human eosinophils. Int $\mathrm{J}$ Immunopharmacol. 1982;4(4):369.

22. Ohnishi $H$, Kosuzume $H$, Inaba $H$, Okura M, Morita $\mathrm{Y}$, Mochizuki $\mathrm{H}$, et al. Mechanism of host defense suppression induced by viral infection: mode of action of inosiplex as an antiviral agent. Infect Immun. 1982;38(1):243-50.

23. Renoux G, Renoux M, Guillaumin J-M. Isoprinosine as an immunopotentiator. J Immunopharmacol. 1979;1(3):337-56. 
24. Morin A, Ballet JJ. A recent overview on in vitro and in vivo immunological activities of methisoprinol. Allergol Immunopathol (Madr). 1982;10(2):109-14.

25. Gordon P, Brown ER. The antiviral activity of Isoprinosine. Can J Microbiol. 1972;18(9):1463-70. https://doi.org/10.1139/m72-224.

26. De Simone C, Prohost JW. Prohost modulation of immunity by isoprinosine and NPT 15392. Antibiosis and host immunity. Boston, MA: Springer; 1987. p. 279-90.

27. Linhares R, Rebello M, Nozawa C. Effect of isoprinosine on rotavirus replication in vitro. Braz J Med Biol Res. 1996;29(2):219-22.

28. Licht K, Hartl M, Amman F, Anrather D, Janisiw MP, Jantsch MF. Inosine induces context-dependent recoding and translational stalling. Nucleic Acids Res. 2019;47(1):3-14. https://doi.org/10.1093/nar/ gky1163.

29. Fudenberg HH, Whitten HD. Immunostimulation: synthetic and biological modulators of immunity. Annu Rev Pharmacol Toxicol. 1984;24:147-74. https://doi.org/10.1146/annurev.pa.24.040184. 001051.

30. Ginsberg T, Hadden J. Immunopharmacology of methisoprinol. Immunomodulation. Boston, MA: Springer; 1984. p. 331-48.

31. Campoli-Richards DM, Sorkin EM, Heel RC. Inosine pranobex. Drugs. 1986;32(5):383-424.

32. Simon LN, Glasky AJ. Isoprinosine: an overview. Cancer Treat Rep. 1978;62(11):1963-9.

33. Tsang PH, Sei Y, Bekesi JG. Isoprinosine-induced modulation of T-helper-cell subsets and antigenpresenting monocytes (Leu M3 $+\mathrm{Ia}+$ ) resulted in improvement of T- and B-lymphocyte functions, in vitro in ARC and AIDS patients. Clin Immunol Immunopathol. 1987;45(2):166-76.

34. Pompidou A, Delsaux M, Telvi L, Mace B, Coutance $\mathrm{F}$, Falkenrodt A, et al. Isoprinosine and imuthiol, two potentially active compounds in patients with AIDS-related complex symptoms. Cancer Res. 1985;45(9 Supplement):4671s-3s.

35. Cillari E, Dieli M, Lo Campo P, Sireci G, Caffarelli A, Maltese E, et al. Protective effect of isoprinosine in genetically susceptible $\mathrm{BALB} / \mathrm{c}$ mice infected with Leishmania major. Immunology. 1991;74(1):25-30.

36. Janíčková O, Ančicová L, Briestenska K, Mistrikova $\mathrm{J}$. The effect of Isoprinosine treatment on persistent infection of Balb/c mice infected with murine gammaherpesvirus 68. Acta Virol. 2017;61(1):32-8.
37. Krastev Z, Jelev D, Ivanova R. Isoprinosine induces a rapid lympho-mononuclear response in adult participants. Med Inf. 2015;2(1):80-5.

38. Corey L, Chiang W, Reeves W, Stamm W, Brewer L, Holmes K. Effect of isoprinosine on the cellular immune response in initial genital herpes virus infection. Clin Res. 1979;27:41A.

39. Galbraith GM, Thiers BH, Fudenberg HH. An openlabel trial of immunomodulation therapy with inosiplex (Isoprinosine) in patients with alopecia totalis and cell-mediated immunodeficiency. J Am Acad Dermatol. 1984;11(2):224-30.

40. Lowy M, Ledoux-Corbusier M, Achten G, Wybran J. Clinical and immunologic response to Isoprinosine in alopecia areata and alopecia universalis: association with autoantibodies. J Am Acad Dermatol. $1985 ; 12(1): 78-84$.

41. Wybran J, Schandené L. Isoprinosine in aphthous stomatitis: clinical improvement associated with enhancement of IL2 production. Int J Immunopharmacol. 1985;7(3):318.

42. Dabrowska-Bernstein B, Stasiak A, Dabrowski M, Pawinska A, Cianciara J, Loch T, et al. Evaluation of the treatment of chronic active hepatitis $(\mathrm{HBsAg}+)$ with isoprinosine II Immunological studies. Pol Tyg Lek. 1990;45(16-18):347-51.

43. Cianciara J, Laskus T, Gabinska E, Loch T. Isoprinosine in the treatment of chronic active hepatitis type B. Scand J Infect Dis. 1990;22(6):645-8.

44. Schinazi RF, Cannon DL, Arnold BH, MartinoSaltzman D. Combinations of isoprinosine and $3^{\prime}$ azido-3'-deoxythymidine in lymphocytes infected with human immunodeficiency virus type 1 . Antimicrob Agents Chemother. 1988;32(12):1784-7.

45. Majewska A, Lasek W, Janyst M, Młynarczyk G. Inhibition of adenovirus multiplication by inosine pranobex and interferon $\alpha$ in vitro. Cent Eur J Immunol. 2015;40(4):395-9. https://doi.org/10. 5114/ceji.2015.56960.

46. Piret J, Boivin G. Resistance of herpes simplex viruses to nucleoside analogues: mechanisms, prevalence, and management. Antimicrob Agents Chemother. 2011;55(2):459-72. https://doi.org/10. 1128/AAC.00615-10.

47. Gupta R, Warren T, Wald A. Genital herpes. Lancet. 2007;370(9605):2127-37. https://doi.org/10.1016/ s0140-6736(07)61908-4.

48. Looker KJ, Magaret AS, May MT, Turner KME, Vickerman P, Gottlieb SL, et al. Global and Regional Estimates of Prevalent and Incident Herpes Simplex 
Virus Type 1 Infections in 2012. PLoS ONE. 2015;10(10):e0140765. https://doi.org/10.1371/ journal.pone.0140765.

49. Looker KJ, Magaret AS, Turner KME, Vickerman P, Gottlieb SL, Newman LM. Global estimates of prevalent and incident herpes simplex virus type 2 infections in 2012. PLoS ONE. 2015;10(1):e114989. https://doi.org/10.1371/journal.pone.0114989.

50. Pinninti SG, Kimberlin DW. Neonatal herpes simplex virus infections. Semin Perinatol. 2018;42(3): 168-75. https://doi.org/10.1053/j.semperi.2018.02. 004 .

51. Mekki M, Eley B, Hardie D. Wilmshurst JM Subacute sclerosing panencephalitis: clinical phenotype, epidemiology, and preventive interventions. Dev Med Child Neurol. 2019. https://doi.org/10.1111/ dmcn.14166.

52. Gutierrez J, Issacson RS, Koppel BS. Subacute sclerosing panencephalitis: an update. Dev Med Child Neurol. 2010;52(10):901-7. https://doi.org/10. 1111/j.1469-8749.2010.03717.x.

53. Tatli B, Ekici B, Ozmen M. Current therapies and future perspectives in subacute sclerosing panencephalitis. Expert Rev Neurother. 2012;12(4):485-92. https://doi.org/10.1586/ern.12. 21.

54. Gadoth N. Subacute sclerosing panencephalitis (SSPE) the story of a vanishing disease. Brain Dev. 2012;34(9):705-11. braindev.2011.12.008.

55. Noetzel MJ, Dodson WE. Progressive CT abnormalities despite clinical improvement in SSPE treated with inosiplex. Ann Neurol. 1983;13(4):457-60. https://doi.org/10.1002/ana.410130416.

56. Solomon T, Hart CA, Vinjamuri S, Beeching NJ, Malucci C, Humphrey P. Treatment of subacute sclerosing panencephalitis with interferon-alpha, ribavirin, and inosiplex. J Child Neurol. 2002;17(9):703-5. https://doi.org/10.1177/ 088307380201700911.

57. Huttenlocher PR, Mattson RH. Isoprinosine in subacute sclerosing panencephalitis. Neurology. 1979;29(6):763-71.

58. Silverberg R, Brenner T, Abramsky O. Inosiplex in the Treatment of Subacute Sclerosing Panencephalitis. Arch Neurol. 1979;36(6):374-5. https:// doi.org/10.1001/archneur.1979.00500420084012.

59. DuRant RH, Dyken PR, Swift AV. The influence of inosiplex treatment on the neurological disability of patients with subacute sclerosing panencephalitis. J Pediatr. 1982;101(2):288-93.
60. Haddad FS, Risk WS. Isoprinosine treatment in 18 patients with subacute sclerosing panencephalitis: a controlled study. Ann Neurol. 1980;7(2):185-8. https://doi.org/10.1002/ana.410070216.

61. Jones C, Huttenlocher P, Dyken P, Jabbour JT, Maxwell K. Inosiplex therapy in subacute sclerosing panencephalitis: a multicentre, non-randomised study in 98 patients. Lancet. 1982;319(8280): 1034-7. https://doi.org/10.1016/S0140-6736(82) 92097-9.

62. Anlar B, Aydin OF, Guven A, Sonmez FM, Kose G, Herguner O. Retrospective evaluation of interferonbeta treatment in subacute sclerosing panencephalitis. Clin Ther. 2004;26(11):1890-4. https:// doi.org/10.1016/j.clinthera.2004.11.002.

63. Anlar B, Yalaz K, Kose G, Saygi S. Beta-interferon plus inosiplex in the treatment of subacute sclerosing panencephalitis. J Child Neurol. 1998;13(11):557-9. https://doi.org/10.1177/ 088307389801301106.

64. Fukuyama Y, Nihei K, Matsumoto S, Ebina $T$, Kamoshita S, Sato T, et al. Clinical effects of MND19 (Inosiplex) on subacute sclerosing panencephalitis-a multi-institutional collaborative study-the Inosiplex-SSPE Research Committee. Brain Dev. 1987;9(3):270-82.

65. Nasirian A, Ashrafi M, Nasrabady SE. Use of A-interferon, amantadin and isoprinosine in subacute sclerosing panencephalitis (sspe): comparing the effectiveness. Iran J Child Neurol. 2008;2(2):27-32.

66. Sobczyk W, Kulczycki J, Piłkowska E, Iwińska B, Milewska D, Szmigielski S. Comparison of the results of the treatment of patients with SSPE using various immunomodulating preparations. Neurol Neurochir Pol. 1991;25(5):626-33.

67. Aydin ÖF, Şenbil N, Kuyucu N, Gürer YKY. Combined treatment with subcutaneous interferon- $\alpha$, oral isoprinosine, and lamivudine for subacute sclerosing panencephalitis. J Child Neurol. 2003;18(2):104-8. https://doi.org/10.1177/0883073 8030180020701 .

68. Häusler M, Aksoy A, Alber M, Altunbasak S, Angay A, Arsene OT, et al. A multinational survey on actual diagnostics and treatment of subacute sclerosing panencephalitis. Neuropediatrics. 2015; 46(6):377-84.

69. Rafique A, Amjad N, Chand P, Zaidi SSZ, Rana MS, Ahmed K, et al. Subacute sclerosing panencephalitis: clinical and demographic characteristics. J Coll Physicians Surg Pak. 2014;24(8):557-60.

70. Mohanty CK, Scott SC. Immunotherapy of genital warts with inosine pranobex (Imunovir): 
preliminary study. Genitourin Med. 1986;62:352-5. https://doi.org/10.1136/sti.62.5.352.

71. Sadoul G, Beuret T. Treatment of cervical and vulvar condylomata by $\mathrm{CO} 2$ laser also with a immunostimulant. Rev Fr Gynecol Obstet. 1984;79(11):681-4.

72. Davidson-Parker J, Dinsmore W, Khan MH, Hicks DA, Morris CA, Morris DF. Immunotherapy of genital warts with inosine pranobex and conventional treatment: double blind placebo controlled study. Genitourin Med. 1988;64(6):383-6.

73. Tay SK. Efficacy of inosine pranobex oral therapy in subclinical human papillomavirus infection of the vulva: a randomized double-blinded placebo controlled study. Int J STD AIDS. 1996;7(4):276-80. https://doi.org/10.1258/0956462961917960.

74. Sand-Petersen C, Weismann K. Isoprenosine improves symptoms in young females with chronic vulvodynia. Acta Derm Venereol. 1996;76(5):404.

75. Kedrova AG, Podisov YI, Kuznetsov VV, Bryugzin VV, Kozachenko VP, Nikogosyan SO. Role of antiviral therapy in the complex treatment of patients with epithelial dysplasias and preinvasive cancer of the cervix uteri. Akush Ginekol. 2006;6:27-30.

76. Georgala S, Katoulis A, Befon A, Georgala C, Rigopoulos D. Short communication: oral inosiplex in the treatment of cervical condylomata acuminata: a randomised placebo-controlled trial. BJOG. 2006;113(9):1088-91. https://doi.org/10.1111/j. 1471-0528.2006.01041.x.

77. Femiano F, Gombos F, Scully C. Oral proliferative verrucous leukoplakia (PVL); open trial of surgery compared with combined therapy using surgery and methisoprinol in papillomavirus-related PVL. Int J Oral Maxillofac Surg. 2001;30(4):318-22. https://doi.org/10.1054/ijom.2001.0066.

78. Pachuta DM, Togo Y, Hornick RB, Schwarts AR, Tominaga S. Evaluation of isoprinosine in experimental human rhinovirus infection. Antimicrob Agents Chemother. 1974;5(4):403-8.

79. Waldman RH, Ganguly R. Therapeutic efficacy of inosiplex (Isoprinosine ${ }^{\circledR}$ ) in rhinovirus infection. Ann N Y Acad Sci. 1977;284(1):153-60.

80. Khakoo RA, Watson GW, Waldman RH, Ganguly R. Effect of inosiplex (isoprinosine) on induced human influenza A infection. J Antimicrob Chemother. 1981;7(4):389-97.

81. Beran J, Šalapová E, Špajdel M. Inosine pranobex is safe and effective for the treatment of subjects with confirmed acute respiratory viral infections: analysis and subgroup analysis from a phase 4, randomised, placebo-controlled, double-blind study. BMC Infect Dis. 2016;16(1):648.

82. Lam KC, Lin HJ, Lai CL, Lam SK, Kwan YL. Isoprinosine in classical acute viral hepatitis. Am J Dig Dis. $1978 ; 23(10): 893-6$.

83. Scasso A, Paladini A, Della Santa M. Methisoprinol in the treatment of acute B viral hepatitis: controlled clinical study. BMC Infect Dis. 1983;34(3):423-35.

84. Nikolova N, Antonov K, Mateva L. Krastev Z Could Inosine pranobex and ribavirin in combination restore immune competence in chronic $\mathrm{HCV}$ advanced liver disease? MedInform. 2014;1:35-44. https://doi.org/10.18044/medinform.201411.35.

85. Pardo M, Carreño V. Lack of efficacy of inosine pranobex in the treatment of chronic hepatitis C. J Hepatol. 1994;21(2):278.

86. Wallace JI, Bekesi JG. A double-blind clinical trial of the effects of inosine pranobex in immunodepressed patients with prolonged generalized lymphadenopathy. Clin Immunol Immunopathol. 1986;39(1):179-86.

87. Pedersen C, Sandström E, Petersen CS, Norkrans G, Gerstoft J, Karlsson A, et al. the efficacy of inosine pranobex in preventing the acquired immunodeficiency syndrome in patients with human immunodeficiency virus infection. $\mathrm{N}$ Engl $\mathrm{J}$ Med. 1990;322(25):1757-63. https://doi.org/10.1056/ nejm199006213222501.

88. Kovacs JA, Powell F, Voeller D, Allegra CJ. Inhibition of Pneumocystis carinii dihydropteroate synthetase by para-acetamidobenzoic acid: possible mechanism of action of isoprinosine in human immunodeficiency virus infection. Antimicrob Agents Chemother. 1993;37(6):1227-31.

89. De Simone C, Famularo G, Tzantzoglou S, Moretti S, Jirillo E. Inosine pranobex in the treatment of HIV infection: a review. Int J Immunopharmacol. 1991;13(Suppl 1):19-27.

90. Georgala S, Katoulis AC, Befon A, Georgala K, Stavropoulos PG. Inosiplex for treatment of alopecia areata: a randomized placebo-controlled study. Acta Derm Venereol. 2006;86(5):422-4.

91. Wybran J, Famaey JP, Appelboom T. Inosiplex: a novel treatment in rheumatoid arthritis? J Rheumatol. 1981;8(4):643-6.

92. Sadowska-Wroblewska M, Wroblewska-Graff T, Werynska-Przybylska J, Rell-Bakalarska M, Kurdybacha J. Isoprinosine in the early pre-erosive stage 
of rheumatoid arthritis: a pilot study. Z Rheumatol. 1988;47(2):113-6.

93. Becker H, Loers E, Helmke K, Federlin K. Therapy of rheumatic diseases with inosiplex. Immun Infekt. 1986;14(3):93-9.

94. Centers for disease control and prevention. What is ME/CFS? 2018. https://www.cdc.gov/me-cfs/about/ index.html. Accessed 15 Feb 2019.

95. World Health Organization. Atlas: multiple sclerosis resources in the world 2008. Geneva: World Health Organization; 2008.

96. Hommes OR, Comi G. Early indicators early treatments neuroprotection in multiple sclerosis. Milano: Springer; 2004.

97. Caltagirone C, Carlesimo A. Methisoprinol in the treatment of multiple sclerosis. A pilot study. Acta Neurol Scand. 1986;74(4):293-6.

98. Mazzarello P, Rocchelli B, Poloni M, Delodovici M, Pinelli P. Isoprinosine in multiple sclerosis treatment: a preliminary study. Schweiz Arch Neurol Neurochir Psychiatr. 1982;131(2):175-9.

99. Pompidou A, Rancurel G, Delsaux M, Meunier C, Telvi L, Cour V, et al. Immunosuppressive effects of isoprinosine in man: a comparison to chlorambucil effects in multiple sclerosis. Cancer Detect Prev Suppl. 1987;1:377-83.

100. Milligan NM, Miller DH, Compston DA. A placebocontrolled trial of isoprinosine in patients with multiple sclerosis. J Neurol Neurosurg Psychiatry. 1994;57(2):164-8.

101. World Health Organization. Global tuberculosis report 2018. 2018.

102. Laurenzi M, Ginsberg A, Spigelman M. Challenges associated with current and future TB treatment. Curr Drug Targets Infect Disord. 2007;7(2):105-19.

103. Mishra AK, Yabaji SM, Dubey RK. Evaluation of isoprinosine to be repurposed as an adjunct antituberculosis chemotherapy. Med Hypotheses. 2018;115:77-80. https://doi.org/10.1016/j.mehy. 2018.04.002.

104. Ompico MG. Methisoprinol for children with early phase dengue infection: a pilot study. Paediatr Indones. 2013;53(6):320-7.

105. Sarciron ME, Delabre I, Walbaum S, Raynaud G, Petavy AF. Effects of multiple doses of isoprinosine on Echinococcus multilocularis metacestodes. Antimicrob Agents Chemother. 1992;36(1):191-4. https://doi.org/10.1128/aac.36.1.191.
106. Sarciron ME, Walbaum S. Petavy AF Effects of Isoprinosine on Echinococcus multilocularis and E. granulosus metacestodes. Parasitol Res. 1995;81(4):329-33. https://doi.org/10.1007/bf0093 1540 .

107. Lawton P, Walchshofer N, Sarciron M. In vitro effects of isoprinosine and a dipeptide methyl ester on Echinococcus multilocularis protoscoleces. J Helminthol. 2001;75(3):251-7.

108. Gascon GG. Randomized treatment study of inosiplex versus combined inosiplex and intraventricular interferon- $\alpha$ in subacute sclerosing panencephalitis (SSPE): international multicenter study. J Child Neurol. 2003;18(12):819-27.

109. Nakamura T, Miyasaka N, Pope RM, Talal N, Russell IJ. Immunomodulation by isoprinosine: effects on in vitro immune functions of lymphocytes from humans with autoimmune diseases. Clin Exp Immunol. 1983;52(1):67-74.

110. Wiranowska-Stewart M, Hadden JW. Effects of isoprinosine and NPT 15392 on interleukin-2 (IL-2) production. Int J Immunopharmacol. 1986;8(1): 63-9.

111. Tsang KY, Donnelly R, Galbraith G, Fudenberg HH. Isoprinosine effects on interleukin-1 production in acquired immune deficiency syndrome (AIDS). Int J Immunopharmacol. 1986;8(4):437-41.

112. Tsang KY, Fudenberg H, Galbraith G, Donnelly R, Bishop L, Koopmann W. Partial restoration of impaired interleukin-2 production and Tac antigen (putative interleukin-2 receptor) expression in patients with acquired immune deficiency syndrome by isoprinosine treatment in vitro. J Clin Invest. 1985;75(5):1538-44.

113. Silvennoinen-Kassinen $\mathrm{S}$, Karttunen R, Tiilikainen A, Huttunen K. Isoprinosine enhances PHA responses and has potential effect on natural killer cell (NK) activity of uremic patients in vitro. Nephron. 1987;46(3):243-6. https://doi.org/10. 1159/000184362.

114. Hersey P, Bindon C, Bradley M, Hasic E. Effect of isoprinosine on interleukin 1 and 2 production and on suppressor cell activity in pokeweed mitogen stimulated cultures of $\mathrm{B}$ and $\mathrm{T}$ cells. Int $\mathrm{J}$ Immunopharmacol. 1984;6(4):321-8.

115. De Simone C, Capozzi C, Campo S, Ricca D, Matteucci G. Effect of azathioprine and inosiplex on rosette formation by lymphocytes from normal donors and from patients with neoplasia. Ann Sclavo. 1981;23:116-24. 
116. Galli M, Lazzarin A, Moroni M, Zanussi C. Inosiplex in recurrent herpes simplex infections. Lancet. 1982;320(8293):331-2.

117. Galli M, Lazzarin A, Moroni M, Zanussi C. Treatment of recurrent viral infectious diseases by methisoprinol. In: Fudenberg $\mathrm{HH}$, Whitten HD, Ambrogi F, editors. Immunomodulation: new frontiers and advances. Boston: Springer; 1984. p. 385-97.

118. Talbot DJ, Menday AP, Saurat JH. Inosine pranobex in mucocutaneous herpes. Lancet. 1985;325 (8433):877. https://doi.org/10.1016/S0140-6736(85) 92239-1.

119. Cutler J, Talbot DJ. The successful treatment of Herpes genitalis with Imunovir (inosine pranobex) 6th International Meeting of the International Society for STD Research; 31st July-2nd August 1985. England: Brighton; 1985.

120. Byrne M, Lawrence A, Walker G, O’Neill O, Csonka $\mathrm{G}$, John J. Suppression of recurrent genital herpes by inosine pranobex: effects of episodic and continuous treatment. BMC Infect Dis. 1988;43(4):681-8.

121. Mindel A, Carney O, Sonnex C, Freris M, Patou G, Williams P. Suppression of frequently recurring genital herpes: acyclovir $\mathrm{v}$ inosine pranobex. Sex Transm Infect. 1989;65(2):103-5.

122. Kinghorn G, Woolley P, Thin R, De Maubeuge J, Foidart J-M, Engst R. Acyclovir vs. isoprinosine (immunovir) for suppression of recurrent genital herpes simplex infection. Sex Transm Infect. 1992;68(5):312-6.

123. Feldman S, Hayes FA, Chaudhary S, Ossi M. Inosiplex for localized herpes zoster in childhood cancer patients: preliminary controlled study. Antimicrob Agents Chemother. 1978;14(3):495-7.

124. Lesourd B, Laude J, Meunier P, Doumerc S, Moulias R. Isoprinosine treatment of herpes zoster. Results of a control study in 36 subjects. Nouv Presse Med. 1982;11(3):191-3.

125. Castelli M, Zanca A, Giubertoni G, Zanca A, Bertolini A. Griseofulvin-methisoprinol combination in the treatment of herpes zoster. Pharmacol Res Commun. 1986;18(10):991-6.

126. Payne CMR, Menday AP, Rogers T, Staughton RC. Isoprinosine does not influence the natural history of herpes zoster or postherpetic neuralgia. Scand J Infect Dis. 1989;21(1):15-8.

127. Yalaz K, Anlar B, Oktem F, Aysun S, Ustacelebi S, Gurcay $\mathrm{O}$, et al. Intraventricular interferon and oral inosiplex in the treatment of subacute sclerosing panencephalitis. Neurology. 1992;42(3 Pt 1):48891.

128. Gascon G, Yamani S, Crowell J, Stigsby B, Nester M, Kanaan I, et al. Combined oral isoprinosine-intraventricular alpha-interferon therapy for subacute sclerosing panencephalitis. Brain Dev. 1993;15(5): 346-55.

129. Anlar B, Yalaz K, Oktem F, Kose G. Long-term follow-up of patients with subacute sclerosing panencephalitis treated with intraventricular alphainterferon. Neurology. 1997;48(2):526-8.

130. Gokcil Z, Odabasi Z, Demirkaya S, Eroglu E, Vural O. Alpha-interferon and isoprinosine in adult-onset subacute sclerosing panencephalitis. J Neurol Sci. 1999;162(1):62-4.

131. Eroglu E, Gokcil Z, Bek S, Ulas UH, Ozdag MF, Odabasi Z. Long-term follow-up of patients with adult-onset subacute sclerosing panencephalitis. J Neurol Sci. 2008;275(1-2):113-6.

132. Zagni G, Cannarozzo C. Clinical trial on the topical application of methisoprinol in some cutaneous viruses. Clin Eur. 1982;21:3-7.

133. Malgouyat J. A new approach to the treatment of genital condyloma in women. Gynecologie. 1983;34(5):415-517.

134. Mihula M. Possible treatment of anogenital warts with the immunomodulation agent Isoprinosine. Prakt Gyn. 2015;19(2):101-6.

135. Nejmark B, Kondrat'eva J, Zologina V, Torbik D. Effectiveness of combined treatment of HPV infection. Urologiia. 2015;2:39-40. 